\title{
ŽIVOT NA HRANICI MESTA. PRÍSPEVOK K VÝSLEDKOM ARCHEOLOGICKÉHO VÝSKUMU VODNEJ VEŽE V BRATISLAVE
}

\author{
PETRA ŠIMONČIČOVÁ KOÓŠOVÁ - HEDVIKA SEDLÁČKOVÁ - BRANISLAV LESÁK - \\ DANA ROHANOVÁ
}

\begin{abstract}
Abstrakt: Predložená štúdia sa venuje nálezom z výskumu Vodnej veže v Bratislave, ktorý bol realizovaný Mestskou správou pamiatkovej starostlivosti a ochrany prírody (MSPSOP) v 70. a 80. rokoch 20. storočia. Analýzou archeologického materiálu sme sa pokúsili doložit’ dve základné funkcie skúmaného areálufunkciu mýtnice na medzinárodnej obchodnej ceste a strategického vojenského bodu, ktorý bol dôležitý pre obranu mesta i hradu. Z výskumu pochádza zaujimavá kolekcia skla, na ktorej sa odrazil hospodársky rast Bratislavy ako významného vinohradníckeho centra. Podrobná typológia a chronológia súboru je podložená výsledkami chemických analýz skla.
\end{abstract}

Kl'účové slová: Vodná veža-obchod-sklo-stredovek-novovek.

Life on the Edge of Town. Contribution to the results of archaeological research into the Vodná veža (Water Tower), Bratislava

Abstract: This study examines the finds yielded by research into the Vodná veža (Water Tower) in Bratislava carried out by the Municipal Heritage Care and Conservation Administration in the 1970s and 1980s. Analyses of the archaeological material were employed to confirm two basic functions of the investigated site, that of a toll house on an international trade route, and of a strategic military point essential for the defence of the town and the castle. The research produced an interesting collection of glass reflecting the economic development of Bratislava as a major winemaking centre. The detailed typology and chronology of the series are based on the results of the chemical analyses of glass.

Key words: Vodná veža (Water Tower) - trade - glass - Middle Ages - modern age.

Vodná veža v Bratislave je zaradená medzi národné kultúrne pamiatky (č. ÚZFF 653/1). Po zániku jej funkcie ako strážnej veže pri dunajskom brode, v prvej polovici 17. storočia, boli jej pozostatky začlenené do novostavieb v rámci novej parcelácie. K opätovnej lokalizácii a odkrytiu jej torza došlo až počas archeologického výskumu bratislavského Podhradia v roku 1964 (Fiala-Plachá-Vallašek 1967). Nasledoval systematický archeologický výskum, najprv od roku 1971 vedený A. Pifflom (1972) a v rokoch 1973 až 1984 K. Klinčokovou (MSPSOP). Stavebno-historický prieskum sa zameral na parcely na Vydrici č. 44, 46, 50 a na Št'ukovej ulici č. 2. Celkovo bolo zrealizovaných 36 sond (Klinčoková-Ferus-Kamenická 1986, 1, 8). Doplnkový archeologický výskum zameraný na severnú čast' pôdorysu prebehol v roku 1988. Celkové výsledky boli publikované vo viacerých štúdiách (Klinčoková-Ferus 1982; Baxa-Ferus-Klinčoková 1989), no zameriavali sa prevažne na popis architektúry.

Mýtnica mala slúžit' ako stanovište mýtnika vyberajúceho poplatky a zároveň bola obranným bodom, z ktorého bolo možné vojensky chránit’ mýtny prechod. Takýto charakter mala Vodná veža v Bratislave určite od polovice 13. storočia (Bartl 1963, 59). Naša štúdia sa pokúša prostredníctvom analýzy archeologického materiálu zistit', nakol'ko sa uvedené funkcie odrazili v materiálnej kultúre.

\section{Obchodné cesty}

Vodná veža stála v dôležitej polohe zo strategického vojenského i obchodného hladiska (Bad'urík 2005, 38). V minulosti dial'kové cesty prechádzali rieky na bezpečných miestach, akými boli brody. Jeden z nich bol na meandrujúcom toku Dunaja v bratislavskom Podhradí. Križovali sa tu viaceré dial'kové cesty. Do jednej z mestských brán, Vydrickej, sa zbiehali dve z nich. Jantárová cesta smerovala viac na sever (spojnica sever-juh) a na západ do Olomouca. 


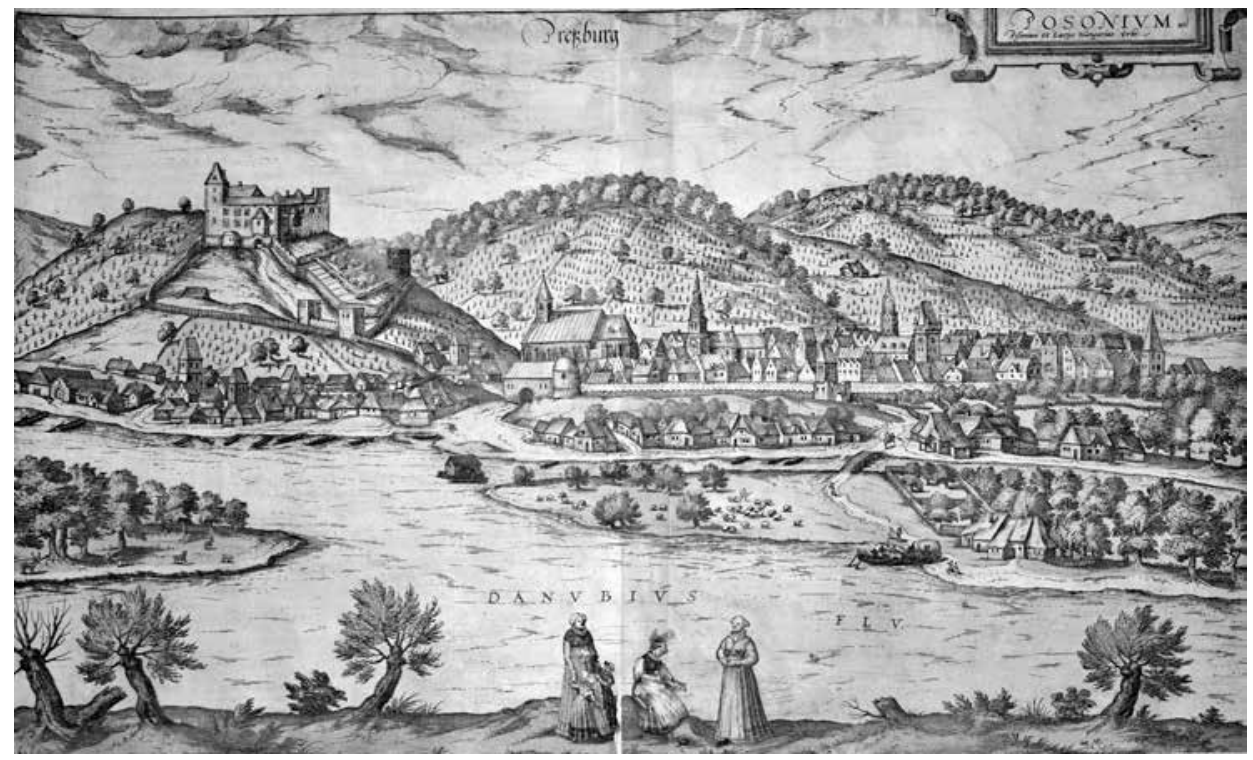

Obr. 1. Vodná veža na vedute Bratislavy, kolorovaná tlač, Franz Hohenberg a Georg Braun, 1593, SNM HM, ev. č. UH02063. Abb. 1. Der Wasserturm auf einer Stadtansicht von Bratislava, kolorierter Druck, Franz Hohenberg und Georg Braun, 1593, Slowakisches Nationalmuseum, Historisches Museum, Evidenznummer UH02063.

Z mesta vychádzala Michalskou bránou. Podunajská cesta, orientovaná v smere východ-západ, pokračovala z rakúskych regiónov do vnútra Uhorska, na Nitru. Z Bratislavy vychádzala Bránou sv. Vavrinca. Smerom na západ obe cesty prechádzali popri Vodnej veži k dunajskému brodu a pokračovali na Viedeň alebo cez Rusovce, Rajku do Mosonmagyaróváru. Dunaj bol dôležitou dopravnou tepnou. Po jeho l'avom brehu prechádzala cesta z Viedne cez Moravské pole, Devín až do Bratislavy. Súbežne po pravom brehu viedla druhá cesta z Viedne, pri Bratislave prechádzala dunajský brod a Vydrickou bránou vchádzala do mesta (Jankovič 1982, 41; Klinčoková-Ferus 1982, 109; Jankovič-Bauerová-Machová 1984; Lysá 2010, 106; 2014, 81-82). Dunajskú cestu využívali juhonemeckí kupci na dopravu svojho tovaru do Uhorska a d’alej na východ. Obojstranný obchod medzi Regensburgom a Kyjevom prechádzal Viedňou i Uhorskom. Pre Bratislavu bola zvlášt' dôležitá blízkost' spomínanej Viedne, kde sa sústredil obchod so západnou Európou, horným Nemeckom, Porýním a, samozrejme, Uhorskom (Bartl 1970, 88). Na ochranu strategického miesta bola postavená Vodná veža. Stála na západnom okraji osady Vydrica, ktorá sa po roku 1291 dostala do právomoci bratislavského župana. Bola najludnatejšou častou Podhradia. V 14. storočí predstavovala jednu ulicu s 23 domami (Weidritz Gassen). Bol tu prístav a mlyny. V pozemkovej knihe Bratislavy (1439-1517) sa tu spomína už 36 nehnutel'ností, z toho 12 slobodných. Stálo tam 33 domov a tri usadlosti boli pusté. Kým v staršom období patrila Vydrica k bratislavskému hradnému panstvu, od roku 1390 bola správne pričlenená k mestu. Odvtedy sa zástavba medzi Vodnou vežou a Vydrickou bránou začala zahust'ovat' (Hudáková 1982, 67; Śášky 1997, 114; Jurányi 2013, 37).

V roku 1430 dal Žigmund Luxemburský oproti Vodnej veži vybudovat' drevený most cez Dunaj, ktorý bol opakovane poškodený. Preto v rokoch 1472-1473 postavili nový most oproti Rybárskej bráne, čím sa čiastočne od Vodnej veže odklonili aj dial'kové komunikácie (Klinčoková-Ferus-Kamenická 1986, 4). 


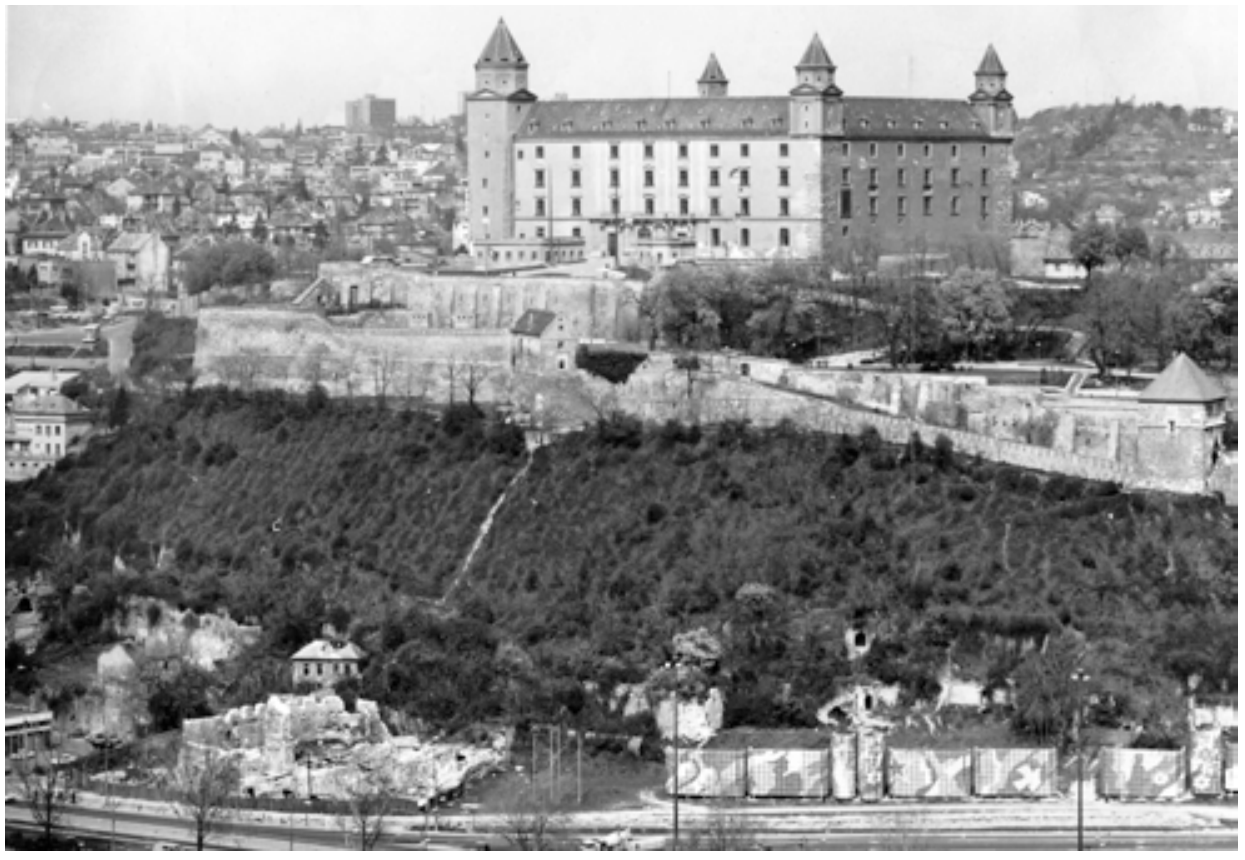

Obr. 2. Vodná veža na fotografii z obdobia výskumu v 70. rokoch 20. storočia. Zdroj Archív MÚOP.

Abb. 2. Wasserturm auf einer Fotografie aus der Zeit der in den siebziger Jahren des 20. Jahrhunderts erfolgten Grabung. Quelle Archiv des Städtischen Denkmalamtes Bratislava.

\section{Bratislavský obchod a mýto}

V stredoveku bol obchod regulovaný dvomi spôsobmi - trhovými privilégiami a mýtnymi či colnými regulatívmi (Kazimír 1987, 20). Dunajský brod v Podhradí možno považovat' za najstarší mýtny prechod v Bratislave (Bartl 1963, 54).

Prvá interpolovaná zmienka o bratislavskom mýte pochádza z roku 1002, z listiny, ktorou pannonhalmský opát dostal od Štefana I. tretinu z uvedeného mýta (Bartl 1982, 46; Lysá 2010, 106). Isté je, že v 12. storočí sa clo vyberané pri dunajskom brode delilo na tri časti. Tretina pripadala bratislavskému županovi, zvyšok si delili dve cirkevné inštitúcie. Tretinu dostávalo cistercitské opátstvo v Piliši a tretinu spomínaný opát benediktínskeho kláštora v Pannonhalme. Najstarším vlastníkom bratislavského mýta bol práve posledný menovaný Kláštor sv. Martina v Pannonhalme. V prípade pilišského opátstva nie je úplne zrejmé, kedy začalo na bratislavskom mýte participovat'. Predpokladá sa, že sa tak stalo najskôr v závere 12. storočia. Listina Bela IV. (1248) obnovuje staršie právo pilišského opáta na tretinu dunajského cla, a zároveň mu král' daroval Vodnú vežu. Okrem uvedených podielnikov, ešte pred rozdelením mýta na tretiny, dostal desiatok z výnosu na základe donácie král’a Imricha II. (1198) aj ostrihomský arcibiskup. V roku 1361 pilišský opát Henrich prenajal Vodnú vežu aj s bratislavským mýtom bratislavskému richtárovi Jakubovi za podmienky, že stavbu nájomca opraví (Bartl 1963, 52-53; 1982, 46; Jankovič 1982, 41; Śášky 1997, 9, 114). Bratislavské mýto bolo v stredoveku chápané ako celok, so svojimi filiálkami, nielen ako mýto vyberané v konkrétnom bode na Dunaji (Bartl 1963, 58).

V stredoveku sa Bratislava stala typickým vinohradníckym mestom, výroba a predaj vína boli primárnym zdrojom príjmov mesta i jeho obyvatel'ov. Rozdiel medzi vinohradníkom a rol'níkom bol v tom, že vinohradník vyrábal preto, aby svoj produkt predal. Rol’ník mal svoju produkciu hlavne na pokrytie svojich potrieb. Tým sa vinohradníci približovali viac remeselníkom 
združovaným v mestách (Kazimír 1986, 19). Plné etablovanie sa vinohradníctva v podunajskej oblasti prebehlo vo včasnom stredoveku, no vel'ký rozmach nastal až v 13. storočí. V tomto období sa začali formovat' vinohradnícke mestečká a jedným z nich bola aj Bratislava. V priestore „vel’kej Bratislavy“ sa pestoval vinič v Devíne, Karlovej Vsi, Lamači, Dúbravke, Záhorskej Bystrici, Rači, Vajnoroch a vo Vrakuni. Na konci 13. storočia používali vlastnú dutú mieru, tzv. bratislavský okov. Prvá zmienka o nej v písomných prameňoch pochádza z roku 1271. Vlastné miery mali aj d’alšie okolité vinohradnícke centrá ako Svätý Jur či Rača (Bad’urík 1990, 30; 2005, 35-37; 2005a, 63-64, 66-67). Po tatárskom vpáde prišli do malokarpatských regiónov nemeckí kolonisti, ktorí nadviazali na staršiu vinohradnícku tradíciu a d’alej ju rozvíjali. Hostia sa stali rozhodujúcou vrstvou pri rozvoji mestského typu vinohradníctva na dnešnom juhozápadnom Slovensku (Bad'urík 1990, 29; 2005, 37-38; 2005a, 65). V bratislavskom privilégiu Ondreja III. (1291) sa spomínajú staré i nové vinohrady, čiže tunajšie vinohradníctvo muselo mat' v tom čase už dlhšiu tradíciu (Horna 1935, 7; Lysá 2010, 109-110). Bratislava získala v roku 1297 prekladové právo,t. j. cudzí obchodníci boli povinní preložit’ svoj tovar na lode Bratislavčanov, a tak ho prepravovat' d’alej do Uhorska. Bratislavské lode mohli vozit' tovar aj na západ, do Rakúska. V čase ekonomického bojkotu Viedne, za vlády Karola Róberta z Anjou (nariadenie z 10. 12. 1324), mali uhorskí obchodníci skladat' svoj tovar v Šoproni. Šopronský obchod s Moravou a českým král’ovstvom prechádzal aj Bratislavou, i ked' hlavná obchodná tepna spájajúca Uhorsko s Českým královstvom, tzv. česká cesta, ju obišla. Až po smrti Karola Róberta došlo $\mathrm{k}$ oživeniu podunajskej cesty. Výrazne k tomu prispelo povolenie pre viedenských kupcov slobodne obchodovat' s Uhorskom po vode i po súši v roku 1346 (Bartl 1970, 92-95; Hudáková 1982, 64). Bratislava bola oslobodená od tridsiatku a mýta aj na tovar od mora (1366), vd’aka čomu udržiavalo mesto čulé kontakty s jadranskou oblastou, Dalmáciou i Benátkami (Bartl 1982a, 69). V 14. a 15. storočí bolo vedenie mesta v rukách najbohatších Bratislavčanov, t. j. asi 7,5 \% vtedajšieho obyvatel'stva. Títo daňovníci platili ročnú daň od 10 do 90 zlatých a ich príjmy pochádzali predovšetkým z vel'koobchodu. Boli medzi nimi najbohatší majstri a majitelia viníc. Kapitál získavali aj z tranzitného obchodu či obchodu s vínom (Bartl-Hudáková 1982, 61). V roku 1401 Bratislava získala právo dovážat' tovar zo zahraničia bez poplatkov, čo bolo potvrdené aj v nasledujúcom roku (Forbat 1959, 18). V bratislavskom Protocollum actionum z rokov 1403-1427 je zachytených 65 záznamov o obchodných kontaktoch domácich s kupcami v Kolíne nad Rýnom (Bartl 1970, 97-98).

Dominantný smer obchodných ciest $\mathrm{v}$ Uhorsku bol od druhej polovice 13. do prelomu 15. a 16. storočia sever-juh, pričom dôležitú úlohu vtedy zohrávalo dnešné východné Slovensko. Od konca 15. storočia sa v rámci zahraničného obchodu zmenilo smerovanie Uhorska na západ, čím stúplo aj postavenie Bratislavy (Halaga 1987, 33, 37-38). Cez Budín, Bratislavu a Viedeň prebiehal čulý obchod s juhonemeckými hanzovými mestami a Benátkami (Hejl 1987, 41).

Mestské privilégiá, ktoré dostala Bratislava od Ondreja III. v roku 1291, podporovali majitel'ov vinohradov napríklad formou odpustenia dávok pre staré i nové vinohrady. Bratislava bola oslobodená od mýta, mala právo obchodovat' bez prekážok v celom Uhorsku, Bratislavčania mohli vol'ne prevážat' tovar cez Dunaj na Žitný ostrov (Bartl 1982, 49; Kazimír 1986, 121; Bad’urík 2005, 38; 2005a, 64). K vývozu bratislavského vína prispela aj podpora zo strany moravského markgrófa Karola, neskoršieho Karola IV., ktorý dvomi listinami pomohol predaju spomínanej komodity na Morave. Výroba bratislavského vína musela byt' v prvej polovici 14. storočia na vel'mi vysokej úrovni. Na jednej strane musela spíňat' požiadavky na kvantitu, aby pokryla dopyt v oblasti vývozu. Dôležitá bola aj kvalita, ked’že sa bratislavské víno presadilo v moravskej a rakúskej konkurencii. Okrem uvedených krajín exportovala Bratislava svoje vína aj na český trh. Postupne si upevnila vedúce postavenie medzi malokarpatskými vinohradníckymi mestami a osadami a stala sa jedným z najbohatších miest Uhorska s dôležitým postavením v rámci zahraničného obchodu. V 15. storočí tvoril najväčšiu čast' príjmov mesta práve obchod s vínom. V období menšej úrody si Bratislavčania žiadali daňovú úlavu $(1348,1371,1397)$. Z malokarpatskej výroby tvoril vývoz do zahraničia asi $20 \%$ produkcie. K podpore domáceho vinohradníctva prispel zákaz bratislavského župana Mikuláša Garaya dovážat' do Bratislavy, 
výskum v roku 1964

지밈 doplnený výskum z roku 1964

\výskum v rokoch 1971-1972

$\square$ výskum v rokoch 1973-1981
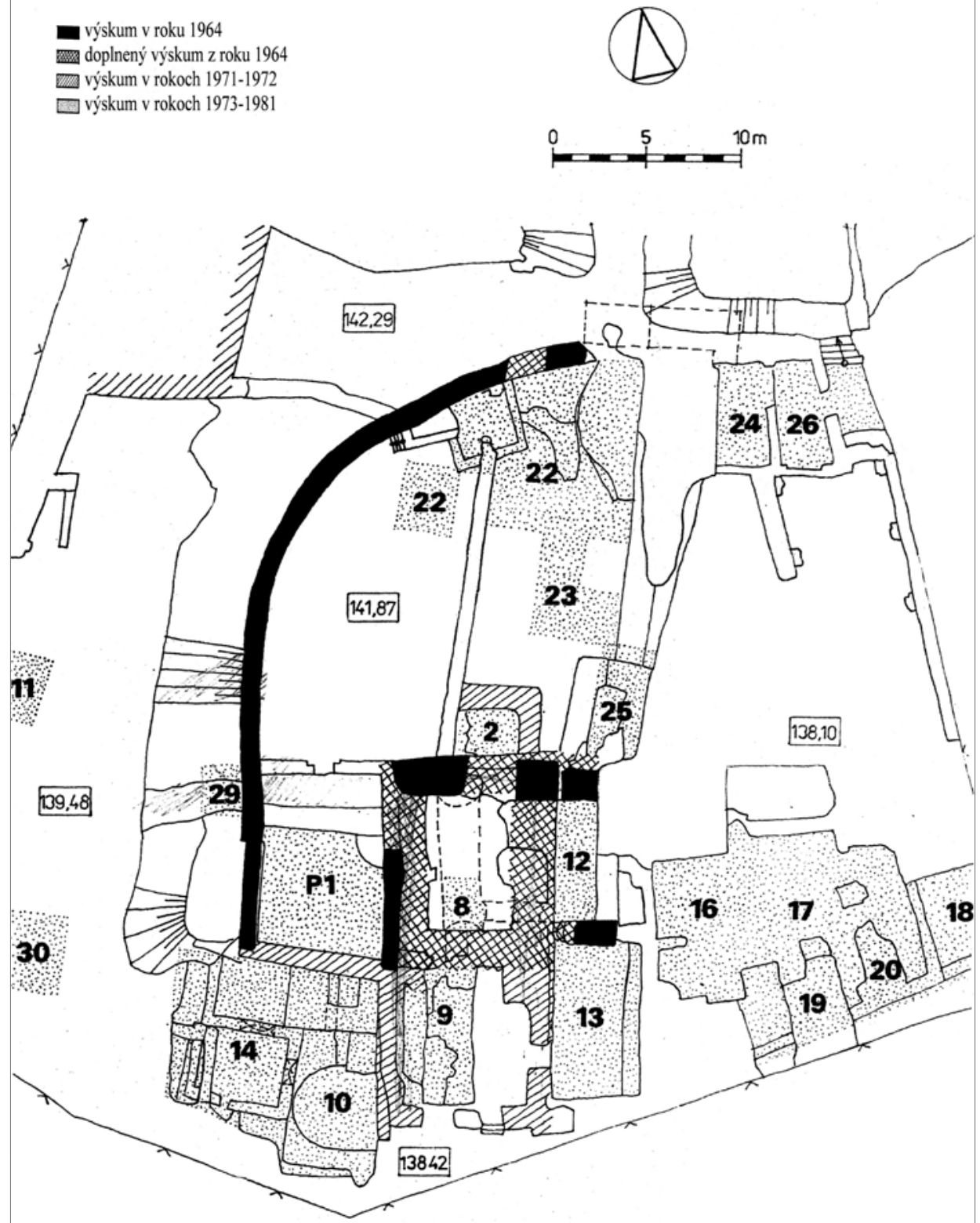

Obr. 3. Pôdorys Vodnej veže s vyznačenými sondami a skúmanými priestormi počas jednotlivých výskumov. Podl’a Klinčoková-Ferus 1982, 127.

Abb. 3. Grundriss des Wasserturms mit eingezeichneten Sondierschnitten und untersuchten Räumen während den einzelnen Grabungen. Nach Klinčoková-Ferus 1982, 127. 
Devína i Rače rakúske vína. Zároveň král’ Žigmund (1418) povolil konfiškovat’ rakúske, štajerské a iné zahraničné vína, ak boli dovezené do Bratislavy nelegálne, čím potvrdil nariadenie obdobného znenia z roku 1354. Bratislavčania mohli dovážat' cudzie vína po zaplatení stanoveného poplatku len pre vlastnú spotrebu. Hostinskí mali možnost' dovážat' víno zo zahraničia iba v malom množstve,t. j. nie celé sudy (Forbat 1959, 22-23; Bartl 1970, 94, 104; Kazimír 1986, 122; Bad'urík 1987, 50; 2005, 40-42, 47; 2005a, 67). V prvej polovici 15. storočia sa obchodu s vínom venovala polovica bratislavských meštanov, ako vyplýva zo súpisu desiatkov pre ostrihomského arcibiskupa (1437) či daňových registrov (1434, 1451/1452; Bartl 1970, 103-104). Dominantné postavenie pri vývoze vín si Bratislava udržala aj za vlády Mateja Korvína. Privilégiá, ktoré od neho mesto dostalo $(1466,1475)$, potvrdili monopol Bratislavy v tejto oblasti. V nariadeniach bolo stanovené, že miestni feudáli, iné mestá ani cudzinci nemohli bez súhlasu Bratislavy obchodovat's uvedenou komoditou (Bad'urík 2005, 42). Na začiatku novoveku zažívalo tunajšie vinohradníctvo jeden zo svojich vrcholov. Po obsadení južného Uhorska Osmanmi malokarpatské vinohradníctvo nahrádzalo výpadok produkcie z južných regiónov král'ovstva. Vrchol v oblasti výroby a obchodu s vínom zažila Bratislava v 16. a 17. storočí (Bad'urík 1987, 50; 2005, 42-43). Ked' sa Bratislava stala hlavným mestom Uhorska (1536), vzrástla aj sláva tunajších vín. Zvýšený dopyt po víne vznikal hlavne v období konania sa snemov. Mesto začalo výrazne regulovat' výčap vína a samo sa stalo najväčším výčapníkom v Bratislave (Bad'urík 1987, 51; 2005a, 68).

Od vlády L'udovíta I. z Anjou mali uhorskí panovníci v Bratislave svojich stálych nákupcov, ktorí zabezpečovali pravidelnú dodávku bratislavských i svätojurských vín na královský stôl. Bratislava posielala víno královi aj ako dar. V odbere bratislavských vín pokračovali aj Habsburgovci po roku 1526. V rokoch 1580 až 1600 nakúpil viedenský dvor 300 okovov (ca 16 2901) bratislavských a svätojurských samotokových vín. Od 16. storočia možno k pravidelným odberatel'om bratislavských vín zarátat' stredoslovenské banské mestá, no svojich spotrebitel'ov nachádzali aj na Žitnom ostrove, na Záhorí, v Trnave, Trenčíne, Žiline, Bytčianskom panstve či spomedzi Thurzovcov na Červenom Kameni (Bad'urík 1987, 51-52; 2005, 46-47; 2005a, 67).

V 15. storočí sa v Bratislave vyrábali prírodné, samotokové, vermútové a pigmentové vína (Kalesný 1982, 73). Exkluzívnym vínom, ktoré možno zaradit' medzi dezertné, bol samotok. V malokarpatskej oblasti sa vyrábal podobným spôsobom ako tokajský výber. Najvhodnejšou odrodou na sušenie bola viridula. Vysušené hrozienka sa zmiešali s čerstvo vylisovaným muštom. Vykvasený čistý mušt zrel v sudoch tri až štyri roky. Najcennejším bol svätojurský samotok, menej kvalitným bol bratislavský a za ním nasledovali račiansky, grinavský a pezinský. Predpokladá sa, že sa vyrábal už na sklonku stredoveku, najneskôr od polovice 16. storočia (Kazimír 1986, 45-46; Bad’urík 2005, 48-49). V malokarpatskej vinohradníckej oblasti sa tradovalo, že bratislavské vinohrady sú najväčšie, svätojurské najlepšie, pezinské najjemnejšie a modranské najúrodnejšie (Kraus 1939, 14). V roku 1465 augsburský pisár Marinus poznamenal, že „prešporské víno sa dobre pije, ale je hudstewer (svinsky drahé), lebo jedno vedro stojí o 32 denárov viac ako talianske Chianti“ (Jurányi 2014, 8).

\section{História Vodnej veže}

Prvá zmienka o Vodnej veži pochádza z roku 1254, ked' tretina dunajského cla pripadala pilišskému opátstvu. Opát Ján dal opravit' Vodnú vežu a postavit' niekol'ko domov pre jeho colníkov pôsobiacich v areáli mýtnice. Komplex, teda „,turrem (...) in castro nostro Posoniensis (...) in loco, qui Wepruch vulgaliter nuncupatur", mohol predstavovat' súčast' hradného fortifikačného systému. V druhej polovici 14. storočia bola stavba opät' v zlom stave. V roku 1361 ju prenajal opát Henrich aj s bratislavským mýtom bratislavskému richtárovi Jakubovi pod podmienkou, že stavbu nájomca opraví. Vtedy prameň uvádza „domum aque vocitatum, Posonii situatam in loco, qui Wepricz nominatur, in portu Danubii“. Prirad'uje ju už k mestu, nie ku hradu. Na jednej strane bola Bratislava v tom čase už plne etablovaným král'ovským mestom s privilégiami (oproti roku 1254), na druhej strane možno uvažovat', že mesto postupne začleňovalo Vodnú vežu medzi svoje obranné pozície. Realizácia opráv bola potvrdená opátom v listine z 19. 7. 1367. Spomínaný 
richtár Jakub sa v roku 1367 uvádza aj ako královský mýtnik, spravujúci malodunajské mýto v Čalove. V roku 1380 sa tu spomína vyberač mýta a pisár. Koncom 14. storočia bola Vodná veža opät' v rukách panovníka. Žigmund Luxemburský v roku 1401 prenajal „král’ovský podiel na Vodnej veži “ bratislavskému meštanovi Jakubovi Bonaventura a jeho synovi Gašparovi za ročný poplatok 30 zlatých. Mali sa starat' o stav a obranu veže, aby z nej nevzišlo nebezpečenstvo pre hrad i mesto. O vzájomnej spolupráci dvoch zložiek podielajúcich sa na bratislavskom mýte svedčí správa z roku 1407 o zadržaní štyroch levočských kupcov služobníkmi pilišského opáta a Gašpara Ventura kvôli pokusu nelegálne vyviezt' dva vozy vosku popri legálne prevážanej medi. V uvedenom roku boli užívatel'mi mýta na Vodnej veži vyššie spomenutí pilišský opát, Jakub Ventura a pán Třmiel von Vattaw (pravdepodobne nájomca panonhalmského podielu). Obe opátstva, t. j. benediktínske pannonhalmské aj cistercitské pilišské, podiel'ajúce sa na bratislavskom mýte, spočiatku vyberali mýto vo vlastnej réžii, neskôr ho i oni prenajímali bratislavským mešt’anom. Mesto sa zároveň podiel’alo na opravách a drobných úpravách areálu, čo od roku 1434 zachytávajú aj výdavky v komorných knihách. V bojoch s husitmi zohrala Vodná veža strategickú vojenskú úlohu - sídlila tu hradná posádka. V roku 1440, počas sporov mesta s hradom, mesto napokon Vodnú vežu dobylo. Rozbroje o strategické miesto pokračovali d’alej. Existenciu Vodnej veže zavíšilo jej obsadenie Bethlénovými vojakmi v roku 1619 a následné dobytie cisárskym vojskom (1620). Generál Henry Duval Dampierre ju dal vyhodit' do vzduchu, čo malo byt' jedným z vojenských preventívnych opatrení. Ako sme už v úvode spomenuli, areál Vodnej veže bol v 17. storočí rozparcelovaný a na jej troskách vyrástli nové stavby (Bartl 1963, 59; Fiala-Plachá-Vallašek 1967, 42-44; Kovačovičová-Puškárová a kol. 1968; Bartl 1970, 102; 1982, 47; 1982a, 70; Klinčoková-Ferus-Kamenická 1986, 3-4; Šášky 1997, 9, 114; Lysá 2014, 97-98).

Ked’že v rokoch 1625-1633 sa pilišský opát snažil o obnovu bývalého kláštora na Vydrici, je možné predpokladat', že Vodná veža nebola úplne zničená a opát iba mylne pokladal fortifikáciu za kláštor. Pilišský opát Tomáš Füley spomína vo Vodnej veži v roku 1625 erárny sklad soli (Kovačovičová-Puškárová a kol. 1968; Klinčoková-Ferus-Kamenická 1986, 5).

Areál stredovekej Vodnej veže bol po jej likvidácii začlenený do komplexov barokových budov, rozprestierajúcich sa na troch parcelách. Nové stavby istým spôsobom pripomínali niektoré z funkcií staršej Vodnej veže. Na východe, Vydrica č. 46, sa rozprestierala budova uhorského Schiffamtu, zastupujúceho funkciu Ministerstva pre vodnú dopravu a styk s Levantom. V rokoch 1780 až 1803 tu sídlil Král’ovský sol'ný úrad. Na západe, Vydrica č. 50, bol vybudovaný trojposchodový tereziánsky reprezentačný hotel, hostinec „U modrej št'uky“. Na juhu, Vydrica č. 48, bol približne v roku 1665 postavený blok budov, v ktorom býval v 18. storočí dozorca lodného tridsiatku. Západne od areálu niekdajšej Vodnej veže bola postavená vodná strážnica (Ankerwache), zabezpečujúca reguláciu kotvenia v prístave (Piffl 1972, 2; Klinčoková-FerusKamenická 1986, 5).

Z architektonického hl'adiska autori výskumu uvažovali o datovaní spodných častí zachovaných murív do obdobia antiky. Do 11. storočia zaradili piliere predmostia zo sekundárne použitých kamenných kvádrov zachytených v telese murív Vodnej veže. Plocha pod mostom bola vydláždená kamennou dlažbou, ktorá ho mala chránit' proti podmývaniu (Baxa-Ferus 1991, 8-9). Súčastou areálu Vodnej veže mohlo byt' podl'a A. Piffla aj prístavisko odkryté južnejšie od nej (Piffl 1972, 11; Klinčoková-Ferus-Kamenická 1986, 7).

Za súčast' fázy spomínanej prameňmi v roku 1254 autori výskumu pokladajú oktogonálnu vežu odkrytú v roku 1988, ktorá by mohla byt' stavbou postavenou z nariadenia pilišského opáta Jána (Baxa-Ferus-Klinčoková 1989, 168; Baxa-Ferus 1991, 16-17). Zo zásypu základovej ryhy veže pochádzala len domáca redukčne vypálená a tuhová keramika, vrátane zásobníc (Baxa-Ferus-Klinčoková 1989, 165-166).

V polovici 14. storočia Vodná veža nebola už len solitérom. Z východu sa ku nej postupne pripájali obytné domy, na juhu sa rozprestieral spomínaný prístav. Z komunikačných i strategických dôvodov ostal priestor zo západu i z juhu nezastavaný (Klinčoková-Ferus-Kamenická 1986, 3). 


\section{Vodná veža ako fortifikácia}

V čase výstavby domov pre colníkov pilišského opáta (1254) komplex Vodnej veže nepatril ani k mestskému, ani k hradnému opevneniu. Osídlenie v tejto časti hradného kopca bolo ešte sporadické. V 12. až 13. storočí bol uvedený priestor často zaplavovaný (Bartl 1982, 47). Pri budovaní mestských hradieb v závere 13. storočia Bratislava nepočítala so spojením svojej obrany s hradom. Postupne boli vybudované dva okruhy hradieb a systém predmestských pevnôstok táborov (Segeš 1998, 12).

Južná a západná strana formujúcej sa Bratislavy nebola spočiatku opevňovaná. Západný úsek hradieb s Vydrickou bránou bol dobudovaný až na prelome 13. a 14. storočia, po udelení mestských privilégií Ondrejom III. (1291). V staršom období plnila Vodná veža teda aj funkciu „mestskej brány“ zo západu (Baxa-Ferus 1991, 16).

$\mathrm{Na}$ čele mestskej domobrany $\mathrm{v}$ Bratislave stál hlavný kapitán. Mesto bolo rozdelené na štyri obvody, na ktorých čele stáli štvrt’majstri (Viertelmeister). Tí mali pridelenú čast' hradieb.

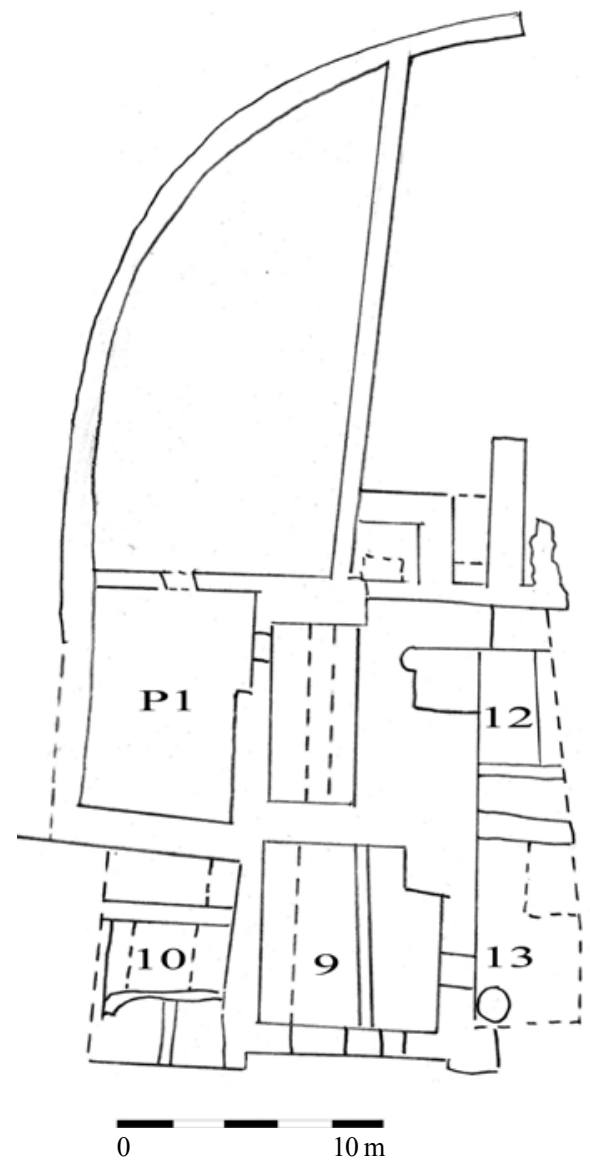

Obr. 4. Pôdorys Vodnej veže $z$ výskumnej dokumentácie z roku 1974 s lokalizáciou studne v sonde 13/73. Zdroj Archív MÚOP.

Abb. 4. Grundriss des Wasserturms aus der Grabungsdokumentation aus dem Jahr 1974 mit Lokalisierung des Brunnens in Sondierschnitt 13/73. Archiv des Städtischen Denkmalamtes Bratislava.
Okrem toho sú v roku 1443 doložení 16 velitelia jednotlivých fortifikačných bodov vrátane Vodnej veže. V uvedenom roku tam velil mestský žoldnier Martin z Brna (Mert von Brün; Segeš 1998, 16; Sedláček 2012, 28-29). Strážnu a hliadkovú funkciu zabezpečovali mestskí strážcovia, kontrolujúci okrem mestských brán aj Vodnú vežu. Prvé zmienky o nich sú $\mathrm{z}$ roku 1373, no podrobnejšie informácie o ich plate máme až z komornej knihy Bratislavy z fiškálneho roka 1434-1435. Kým na mestských bránach boli rozlišované dva typy strážnikov - denný a nočný, na Vodnej veži sa uvádza len wachter. P. Sedláček predpokladá, že to bolo z dôvodu ubytovania žoldnierov v priestore Vodnej veže. V roku 1442 sa tu spomína aj nočný strážnik. Od 50. rokov 15. storočia bol $\mathrm{v}$ mestských účtoch na každej mestskej fortifikácii uvádzaný len jeden strážnik. Ich najímanie mal na starosti mestský kapitán. Mzdu im týždenne vydával mestský komorník alebo mestská rada. Na začiatku fiškálneho roka 1434-1435 mal strážnik na Vodnej veži, podobne ako na väčšine ostatných strážnych bodov Bratislavy, 9 šilingov denárov týždenne a na jeho konci mal denný strážnik na Vodnej veži 60 denárov a nočný len 9 denárov týždenne. $\mathrm{V}$ roku 1434 sa týždenná mzda mestských strážnikov pohybovala okolo 270 až 300 denárov, o desat' rokov neskôr to bolo už len 60 denárov týždenne. Uvedená výška mzdy ostala nezmenená v podstate do konca stredoveku, i ked' na moste a v radničnej veži zarábali strážnici aj dvojnásobok. Mesto zároveň zabezpečovalo uvedeným zamestnancom palivové a stavebné drevo, zvonce, látku na rovnošaty, sviečky a pod. Platovo boli odstupňované rôzne stráž- 
ne funkcie v meste. V roku 1455 bol týždenný plat mestského strážnika 60 až 80 denárov (ako sme uviedli vyššie), žoldnier-pešiak dostával 100 denárov, žoldnierovi-jazdcovi a žoldnierskemu kapitánovi vyplácalo mesto 100 až 240 denárov a hlavný mestský kapitán dostával 240 denárov. (Sedláček 2012, 64-65; 2013, 10-11, 14).

V roku 1440-1441 uvádzajú mestské knihy na Vodnej veži jedenást’ ubytovaných žoldnierov pod vedením kapitána Pavlíka. Mesto im zabezpečovalo drevo na kúrenie a varenie. V roku 1440 dal komorník kapitánovi Pavlíkovi aj šest' nových vlnených diek (Sedláček 2012, 48-49). Je to obdobie bojov medzi hradom a mestom po smrti Albrechta Habsburského, kedy Bratislava zásobovala posádku na Vodnej veži zbraňami, stravou a financovala aj opravy stavby počas bojov (Fiala-Plachá-Vallašek 1967, 43-44). V tom čase, t. j. v roku 1440, bol osobitným velitel'om na Vodnej veži Andrej Bessnew, ktorému mesto nevedelo včas splatit’ dlh vo výške 160 zlatých (Kovačovičová-Puškárová a kol. 1968). V čase, ked’ na Vodnej veži velil už spomínaný Martin z Brna (1443), bol vypracovaný inventár palných zbraní na mestských fortifikáciách. V sledovanej lokalite boli k dispozícii jedna tarasnica, jedna malá puška a celkovo 12 ručníc a hákovníc (Durdík 1967, 591; Segeš 1998, 16).

V roku 1453 král' Ladislav Pohrobok vyzýval mesto, aby Vodnú vežu odovzdalo hradnému velitel'ovi Hansovi Keplerovi, ktorý ju mal strážit' spolu s hradom (Kovačovičová-Puškárová a kol. 1968).

Pri modernizácii predsunutého opevnenia Bratislavy v 16. storočí zostala Vodnej veži zachovaná obranná funkcia, ktorú plnila až do roku 1620 (Fiala 1982, 81).

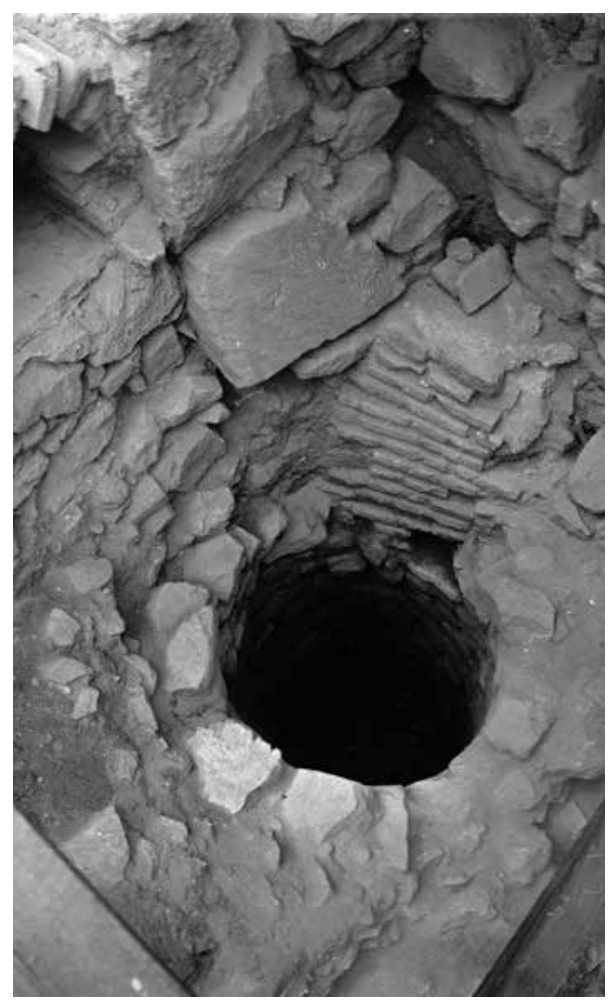

Obr. 5. Bratislava, Vodná veža. Studňa v sonde 13/73, fotografia z výskumnej dokumentácie. Zdroj Archív MÚOP. Abb. 5. Bratislava, Wasserturm. Brunnen in Sondierschnitt 13/73, Fotografie aus der Grabungsdokumentation. Quelle Archiv des Städtischen Denkmalamtes Bratislava.

\section{Archeologické nálezy z Vodnej veže}

Na základe vyššie uvedených skutočností, viažucich sa na funkciu Vodnej veže, sme sa pokúsili zistit', nakol'ko sa jej vojenská funkcia a umiestnenie mýtnice $\mathrm{v}$ uvedenej lokalite odzrkadlili $\mathrm{v}$ archeologických nálezoch. Pracovali sme predovšetkým s výskumnou dokumentáciou, poznámkami k výskumu a kresbovou dokumentáciou nálezov z výskumu MSPSOP. So samotnými nálezmi sa pracuje už tažšie. Nie každý nález je možné stotožnit's konkrétnou polohou alebo prírastkovým číslom. Okrem toho sa v archíve MÚOP nenašla čast' prekreslených nálezov ani vo forme prírastkového katalógu (ca $10 \%$ ).

Naším prvým predpokladom bolo, že na mýtnici, v mieste prvého kontaktu zahraničného tovaru, by bolo možné nájst' importy rôzneho druhu, ako aj cudzí numizmatický materiál. Vodná veža bola zároveň fortifikáciou, kde boli ubytovaní žoldnieri i strážcovia, teda nálezový materiál by mal odrážat' aj vojenskú funkciu lokality.

Najväčšou položkou medzi nálezmi bola jednoznačne keramika, takmer výlučne domáceho pôvodu. $Z$ chronologického hl'adiska sú výrazné tri horizonty - najstarší z 11.-13. storočia $\mathrm{s}$ nálezmi vel'kých zásobníc, vrcholnostredoveký s typickou gotickou keramikou a najmladší novoveký horizont obsahujúci 
aj zlomky kachlíc. Medzi importy možno zaradit' zlomok loštického pohára, taliansku majoliku zo 16. storočia, pôvodom pravdepodobne z Benátok, a novovekú kameninu. Zlomky kameniny pochádzajú zo sondy 1 a 8 , z vrstiev s materiálom datovaným od 16. storočia. Talianska majolika sa našla v studni, v sonde 13, o ktorej budeme ešte hovorit' v súvislosti so súborom skla. Najstarší keramický import, loštická keramika, pochádza zo sondy 8, v ktorej bol počas výskumu zachytený pilier predmostia, zasypaný deštrukčnou vrstvou a splachmi z hradného kopca (Klinčoková-Ferus 1989, 70-71).

Sklo je podl’a prírastkových katalógov z Vodnej veže zriedkavým nálezom. Medzi nálezmi je väčšia kolekcia pochádzajúca zo studne v sonde 13, ktorej sa podrobne venujeme nižšie. Okrem uvedeného súboru sa sklo našlo v sondách 14, 24, 26 a P1, ktoré boli skúmané v južnej a severovýchodnej časti areálu. $\mathrm{O}$ aké konkrétne nálezy išlo, sa nám nepodarilo zistit', ked’že neboli ani nakreslené, ani popísané a ani sa nám ich nepodarilo fyzicky nájst'.

Numizmatické nálezy sú pomerne skromné. Vo výskumnej dokumentácii sa nachádzajú dva odovzdávacie protokoly so zoznamom mincí z Vodnej veže, ktoré nie sú totožné. Prvý z roku 1974/1976 (Fiala 1974) spomína hlavne starší numizmatický materiál. Prevažujú v ňom jednoznačne mince Žigmunda Luxemburského, ktoré sa našli v sonde 10, v blízkosti veže. Rovnako datované mince sa našli aj v sonde označenej ako P1/82 (kamenná plná bašta), v ktorej pokračovala fortifikácia zo sondy 10 . V tomto priestore, v južnej časti areálu Vodnej veže, bola pravdepodobne zachytená vodná priekopa patriaca $\mathrm{k}$ stredovekej veži. Z jej zásypu pochádzal materiál datovaný do 15 . storočia a spomínané mince. K zániku priekopy došlo po vybudovaní obranného múru na konci 14. storočia, čím stratila svoj význam a zasypali ju (Klinčoková-Ferus-Kamenická 1986, 11, 16; Archív MÚOP, inv. č. 4498 I). Ostatné z mincí zo staršieho zoznamu (Fiala 1974) majú tiež domáci, uhorský pôvod a boli vyrazené za vlády Albrechta Habsburského (1), Ferdinanda I. (2) a Mateja II. (2). Čast' súboru nebola určená. Mladší zoznam mincí (Zmluva 2003) uvádza iné, hlavne mladšie nálezy, datované do 18. a 19. storočia. Pochádzajú z obdobia po zániku Vodnej veže. Pri nich však nie je zachytený nálezový kontext.

K militáriám, ktoré by dokladali prítomnost' vojenských zložiek na lokalite, možno zaradit' strelky šípov do luku a do kuše (sondy 2, 3, 5, 8, 12, 14A, 17, 21 a pri murive č. 49), delové gule (v sondách 2 a 24) a snád' aj podkovy (sondy 12, 14A, 14B, 17, 18, 21, 24). Mnohé kovové predmety boli t’ažko identifikovatel’né kvôli rozsiahlej korózii. V súbore z Vodnej veže možno militáriá považovat' za zriedkavé nálezy. Sondy, v ktorých sa našli, sa sústred’ovali v južnej a juhovýchodnej časti areálu Vodnej veže,t. j. v miestach prístupu. Iba dve sondy, č. 21 a 24, boli situované na severe a severovýchode skúmanej plochy (Klinčoková-Ferus 1989, 70-72). Pochádzali z nich predovšetkým podkovy, a je teda možné v tých miestach predpokladat' najskôr stajne. Archeologický materiál nám nepotvrdil výrazné zastúpenie vojenskej zložky v priestore Vodnej veže.

\section{Súbor skla z Vodnej veže}

Zaujímavou vzorkou je súbor skla zo studne zo sondy č. 13/73 (obr. 4, 5), ktorá bola zasypaná v záverečnom období fungovania Vodnej veže. Aspoň na tejto menšej kolekcii sa pokúsime zhodnotit' provenienciu tamojších nálezov. Analýzu a rozbory skla realizovala H. Sedláčková v spolupráci s D. Rohanovou. ${ }^{1}$ Nálezy skla sú v súčasnosti deponované v priestoroch Mestského ústavu ochrany pamiatok v Bratislave (MÚOP) v samostatných vreckách s prírastkovými číslami. Netvoria však súvislý rad, ale sú prerušované číslami skla z iných bratislavských lokalít. V tabul'ke I a II sú zobrazené všetky nálezy usporiadané z typologického hl'adiska.

Nález studne môžeme priblížit' len na základe dostupných informácií z poznámok a výskumnej dokumentácie z Vodnej veže. Studňa s kamenným vencom sa našla v južnej časti skúmaného areálu. V juhozápadnom rohu sondy 13 , asi $50 \mathrm{~cm}$ pod úrovňou vtedajšieho terénu, bola zachytená tehlová klenba. Po jej odstránení sa objavila zasypaná studňa. Jej vrchná čast' mala

1 V príspevku sú použivané výsledky chemických analýz i iné poznatky, získané v rámci grantového projektu GAČR č. P405/12/1411 "Renaissance glass and beginnings of Baroque glassmaking in archaeological finds in the region of the Central Danube region", ktoré boli zverejnené v publikácii Sedláčková-Rohanová et al. 2016. 


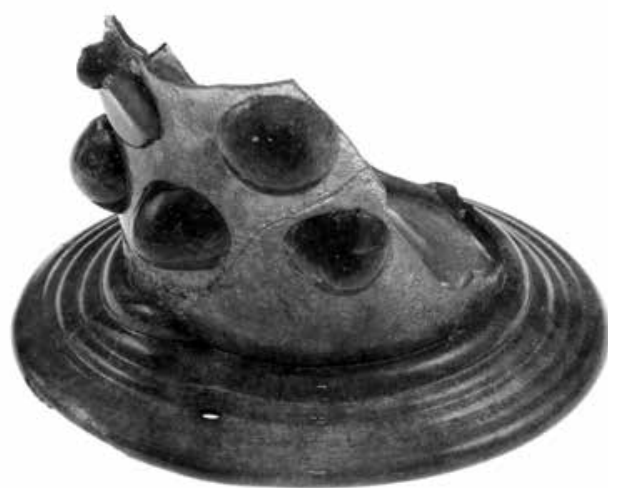

Obr. 6. Bratislava, Vodná veža. Stangenglas patrně uherské provenience ze studny, sonda 13 . Foto Miloš Strnad. Abb. 6. Bratislava, Wasserturm. Stangenglas offenbar ungarischer Provenienz aus dem Brunnen, Sondierschnitt 13. Foto Miloš Strnad.

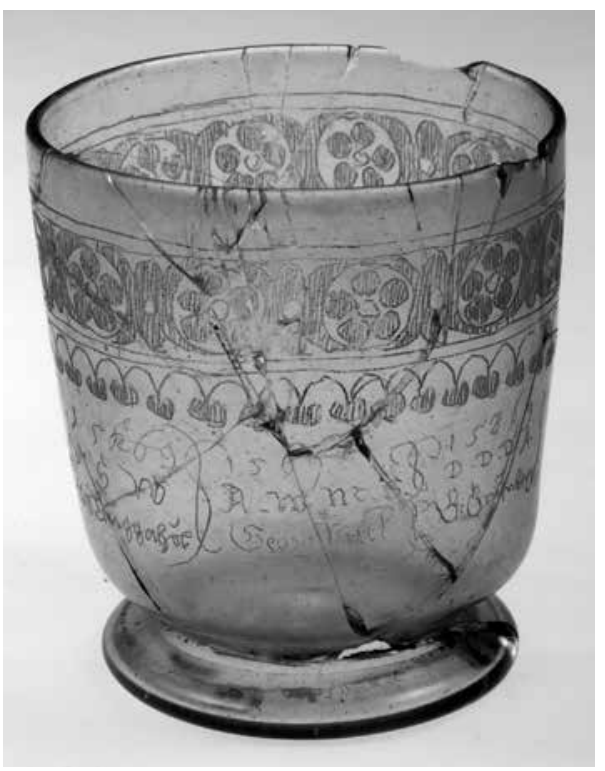

Obr. 7. Bratislava, Vodná veža, sonda 13 , studna. Číška s rytým letopočtem „1569“ a jmény ,f. Khamper / M. Linggahol / Georg Vitt(e) I / B Gruenberg“. Foto Miloš Strnad. Abb. 7. Bratislava, Wasserturm, Sondierschnitt 13, Brunnen. Becher mit eingravierter Jahreszahl „1569“ und den Namen „f. Khamper / M. Linggahol / Georg Vitt(e) l / B Gruenberg“. Foto Miloš Strnad. větší skupina zahrnuje nápojové sklo jako celou číšku, konvičku, poháry, další poutnické láhve, stolní a zásobní láhve, lampy a laboratorní přístroje.

Souboru vévodí celá válcovitá číška $\mathrm{z}$ lehce nazelenalého, čistého skla se zaškrceným prstencem u dna (tab. I:6, obr. 7; Ø okr. 7,2 cm, Ø dna 5,6 cm, v. 8,2 cm, s. skla 0,3 cm; Janovíčková 2001, 46-47). Pod okrajem je pás s rytým dekorem květů, pod ním ryté sloupce s nápisy,

kruhový prierez. Nižšie boli na jej stavbu použité kamenné kvádre a pôdorys sa zmenil na štvorcový. V spodnej časti studne boli zachytené stopy výdrevy. Vyčistená bola pravdepodobne do úrovne ca $550 \mathrm{~cm}(132,50 \mathrm{~m} \mathrm{n.m.)}$. Jej vonkajší priemer dosahoval okolo $120 \mathrm{~cm}$ a vnútorný ca $60 \mathrm{~cm}$. Hrúbka muriva vo venci studne sa pohybovala okolo $30 \mathrm{~cm}$. Výpln̆ tvoril suchý kamenný násyp, pod ktorým nasledoval náplavový riečny piesok. Pochádzajú z nej nálezy keramiky a skla datované do 16.-18. storočia. Podl'a prírastkového katalógu bolo celej kolekcii pridelené jedno číslo 1684 (v roku 1973), eventuálne 4831 v roku 1981 (Klinčoková-Ferus-Kamenická 1986, 13; Archív MÚOP, inv. č. 4498 I, 4498 B).

Soubor skla ze studny ve Vodné veži je druhý největší renesanční nález z Bratislavy. Počtem exemplářů následuje za souborem ze studny 1/01 na Ventúrské 3 (Lesák 2009). Důvodem početnosti nálezů skla může být jednak dlouhodobé zaplňování těchto studen, druhotně sloužících jako odpadní jímky, ale také kompletní prozkoumání obou objektů. Oba soubory totiž vznikaly od první poloviny 16 . století a byly uzavřeny kolem roku 1620. Datování skla z Vodné veže však vychází hlavně z typologického rozboru, nebot' se dochovaly jenom minimální informace o vrstvách či hloubkách, ve kterých byly zlomky nalezeny.

Z Vodné veže pocházejí zlomky a torza šesti desítek nádob a jedna celá číška. Typologicky starší skupinu představují nádoby z modrozeleného skla, které má na povrchu hnědé zkorodované vrstvy. Patří do ní spodní část stangenglasu na patce ze svinutého vlákna a s menšími, oblými nálepy (tab. I:4, obr. 6), zlomky horní části poutnické láhve se žebry (tab. I:1), kutrolfy (tab. I:26, tab. II:9) a několik lahví se žebry, z nichž se zachovala hrdla s vykloněnými okraji a zlomky těl (tab. I:2, 3). Složení tohoto skla je ještě gotické a vyrábělo se v uherských sklárnách.

Nálezy z bezbarvého skla $s$ našedlým nádechem, nazelenalé nebo světle zelené barvy patří do doby po polovině 16 . století. Tato 


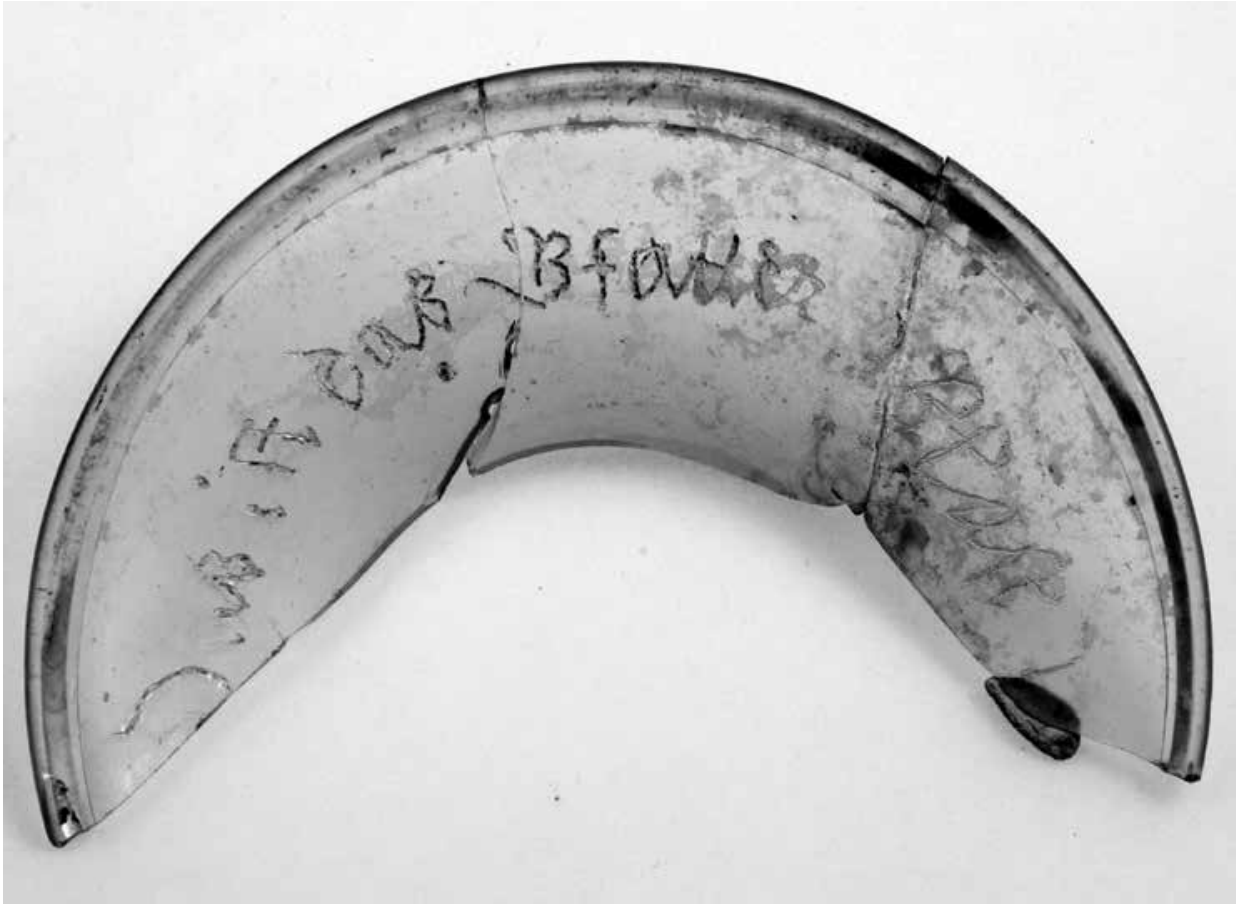

Obr. 8. Bratislava, Vodná veža, sonda 13, studna. Patka poháru s částí rytého nápisu „...Das ist das Stadt...“. Foto Miloš Strnad.

Abb. 8. Bratislava, Wasserturm, Sondierschnitt 13, Brunnen. Becherfuß mit einem Teil der eingravierten Inschrift ,...Das ist das Stadt....". Foto Miloš Strnad.

obsahující letopočet, písmena a jména (čteno zleva): „15A69/VmB /f. Khamper“; „15K69/a.s.w./ M. Linggahol“; „1569 /A.w. m.s. / Georg Vitt(e) l“; „,15B69 / D.D.D.A / B Gruenberg“. Ze čtyř jmen vyrytých pod letopočty bylo možné identifikovat ,f. Khamper", což byl člen rakouského rodu Khamperu ze Scharffenecku u Badenu. V Bratislavě byl majitelem domu na Ventúrské 8 a renesanční kurie v Zuckermandlu (postavená v roce 1565), v podhradní nově vznikající čtvrti západně od Vodné veže (Federmayer 2003, 57-58). Jména dalších tř́i mužů jsme v bratislavských pramenech neidentifikovali.

Číška je nesporným dokladem tzv. Stubengesselschaft, což byly pánské společnosti, ve kterých se u vína debatovalo o politice. Členství bylo podmíněno vysokým finančním příspěvkem, nebo darem poháru či číše, na které byla vyryta jména členů a letopočty. V muzejních sbírkách se dochovaly četné exempláře, často pokryté mnoha letopočty a jmény. Př́iklady uvádí Dieter Scheich v souvislosti s humpenem z Lindau s osmi jmény a letopočty 1555, 1584 a 1630: číši s víkem z Corning Museum of Glass s daty v rozmezí 1578 až 1706 a desítkami jmen a dva poháry z Germanisches Nationalmuseum v Norimberku s letopočty v rozmezí 1556 až 1587 (Scheich 2015). Pohár s bílým filigránem a desítkami jmen vyrytých v pruzích bezbarvého skla z první poloviny 16. století je znám z Nizozemí (Laméris 2013, 16). Tyto společnosti byly oblíbené zejména v rakouských zemích, zvláště v Tyrolích (Egg 1962, 18, 19), odkud také F. Khamper pocházel. Provenienci číšky by nejlépe objasnilo provedení chemických analýz, vzorek však vzhledem ke kompletnosti nádoby nebyl odebrán. Sklo bylo velmi dobře dochované a není vyloučeno, že číška byla produktem sklárny v Hall, která v daném období produkovala vápenato-sodno-draselné sklo (tzv. mixed-alkali glass; Rohanová, nepublikované výsledky). V Bratislavě není tato nádoba 


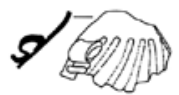

1

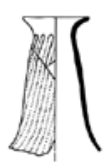

2

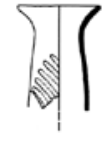

3

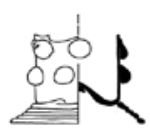

4

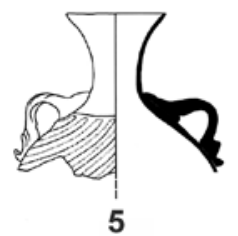

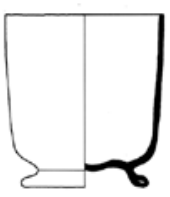

6

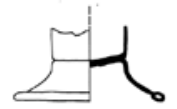

7

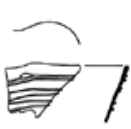

8

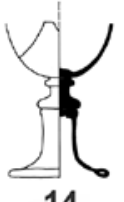

12
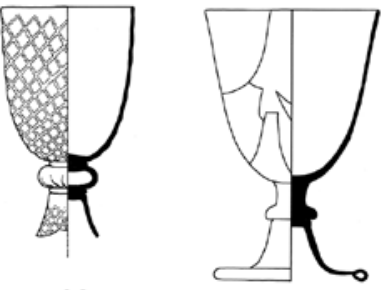

13

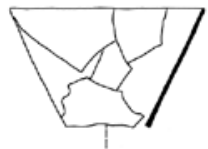

19

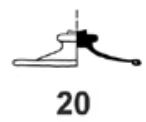

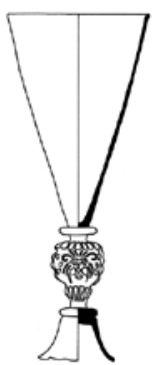

15
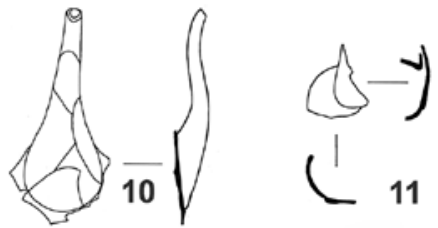
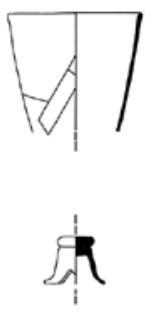

16

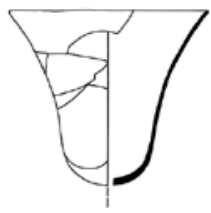

17

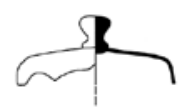

23

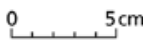

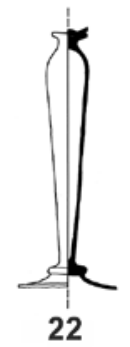

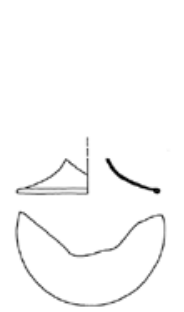

21

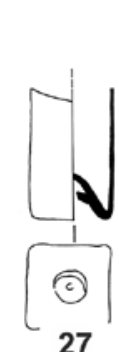

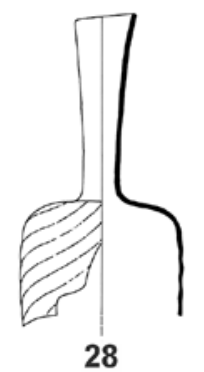

Tab. I. Bratislava, Vodná veža. Sklo ze studny, sonda 13. Kresba Hedvika Sedláčková, technická úprava Lenka Sedláčková. Taf. I. Bratislava, Wasserturm. Glas aus dem Brunnen, Sondierschnitt 13. Zeichnung Hedvika Sedláčková, technische Aufbereitung Lenka Sedláčková. 


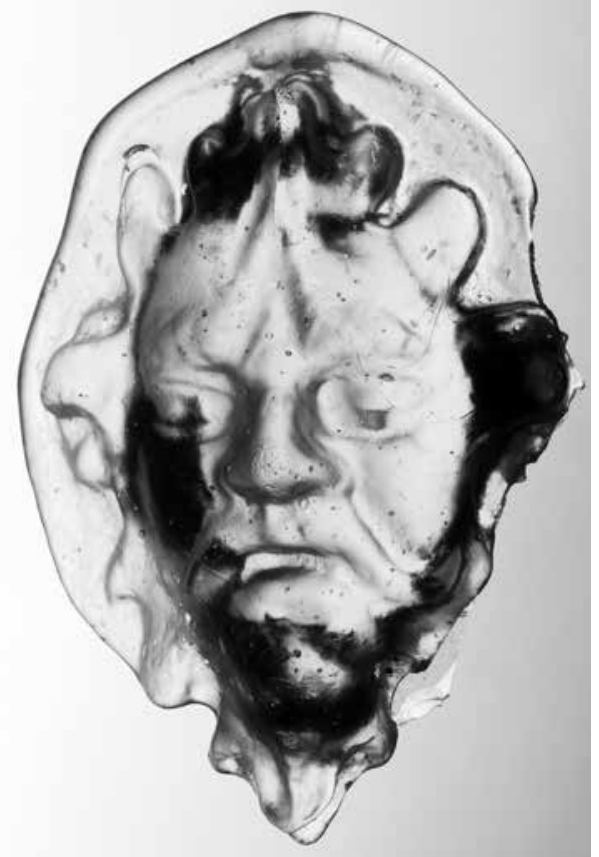

Obr. 9. Bratislava, Vodná veža, sonda 13, studna. Nálep s maskaronem. Foto Miloš Strnad.

Abb. 9. Bratislava, Wasserturm, Sondierschnitt 13, Brunnen. Aufschmelzung mit Maskaron. Foto Miloš Strnad. s rytými nápisy ojedinělá, ovšem na dalších se dochovala jen torza nápisů - na zlomku patky poháru rovněž z Vodné veže ,... Das ist das Stadt..." (tab. I:21, obr. 8), patka s nápisem „Vine memor..." pochází ze studny na Ventúrské 3 (Lesák 2009, 25, obr. 2:11). Další ryté nápisy jsou na skle ze Zelené ulice 1 (Maruniaková 1991).

Jiné číšky se v souboru a ani v Bratislavě nevyskytly. Spodní částí je zastoupena pouze válcovitá číše na duté zvonovité patce (tab. I:7), která v Bratislavě rovněž nepatřila k oblíbeným tvarům.

Unikátní nález představuje také nálep s otiskem kolku s plastickým mužským obličejem z lehce nazelenalého, čistého skla (tab. I:9, obr. 9). Nálep může pocházet z konvičky, ze které se dochoval také zlomek ústí ovinutého vlákny a téměř celá trubicová výlevka (tab. I:8, 10). V 17. století je vyráběly sklárny v Muranu, přričemž nálepy byly nataveny na obvodu největší výdutě konvičky (Dorigato 2013, 110). Nálepy s podobnými maskarony se objevují i na nádobách jiných tvarů, které jsou pokládány za výrobky skláren $\mathrm{v}$ Antverpách. Dokonce lze konstatovat, že bratislavský nálep byl vyroben stejným kolkem jako nálepy na zvonku z poslední čtvrtiny 16 . století z Historického muzea $\mathrm{v}$ Amsterdamu (Vreeken 1998, 131, č. kat. 95). Jinou konvičku reprezentuje drobný zlomek těla s částí trubicové výlevky ze zcela bezbarvého skla (tab. I:11). Pochází z tak drobného tvaru, že se mohlo jednat o dětskou hračku. V Bratislavě je to jediný exemplář této kategorie a ani v jiných městech nebývají hojné - například v Brně byl džbánek z fialového skla na Orlí ulici 10 (Jordánková-Sedláčková 2005, bar. př́loha č. III a IV).

Větší skupinu tvoří poháry, z nichž několik se dochovalo ve velkých torzech. Na prvním místě to je pohár s vyšší polovejčitou kupou a velkým dutým stlačeným nodem, který je kompletně zdobený optickým dekorem rout ( $\varnothing \mathrm{okr} .6,6 \mathrm{~cm}, \varnothing$ nodu $2,8 \mathrm{~cm}$, v. kupy $7,7 \mathrm{~cm}$; Janovíčková 2001, 46). Byl vyroben z lehce našedlého skla draselno-vápenatého složení, tedy v některé regionální sklárně (tab. I:12, obr. 10). Také u dalších, lépe dochovaných pohárů byl prokázán regionální původ: ze skla vápenato-draselného byl vyroben pohár s hladkou polovejčitou kupou a plným prstencem na dříku (tab. I:13; Ø okr. $8,6 \mathrm{~cm}, \varnothing$ patky $7,6 \mathrm{~cm}, \mathrm{v} .13,5 \mathrm{~cm}$ ), což lze předpokládat i u torza stejného poháru (tab. I:14). Vápenato-draselné složení má také pohár $\mathrm{s}$ vřetenovitou kupou s nodem se lvími maskarony (tab. I:15; Ø okr. $7 \mathrm{~cm}$, v. torza 17,2 cm) a lze je předpokládat i u torza poháru stejné varianty (tab. I:16; Sedláčková-Rohanová et al. 2016, 300, tab. 25, A384-386). Z ostatních pohárů z bezbarvého skla s našedlým nádechem zůstaly jen zlomky trychtýřovitých kup (tab. I:18, 19), vysoký balustrový dř́́k (tab. I:22) a terčovitá patka (tab. I:20). Výjimečné je torzo kalichovité kupy ze sytě fialového skla (tab. I:17; Ø okr. 9,5 cm). Ačkoliv jeho analýza nebyla provedena, je pravděpodobné draselné složení, nebot' sklo tohoto typu měla všechna analyzovaná fialová skla z Moravy, Bratislavy i Vídně.

K pohárům a číším patřila víka, která jsou v renesančních souborech vzácná. Z Vodné veže máme doklad jednoho exempláře (tab. I:23). 


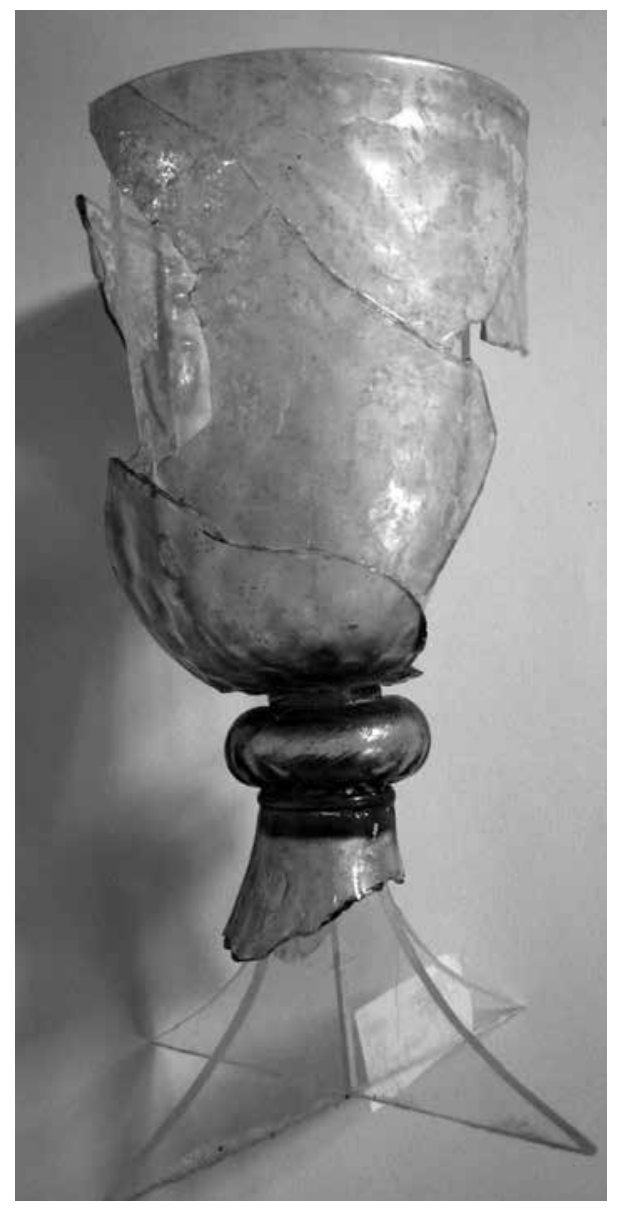

Obr. 10. Bratislava, Vodná veža, sonda 13, studna. Pohár s optickým dekorem rout, regionální výrobek. Foto Hedvika Sedláčková.

Abb. 10. Bratislava, Wasserturm, Sondierschnitt 13, Brunnen. Becher mit optischem Rautendekor, regionales Erzeugnis. Foto Hedvika Sedláčková.
Do kategorie stolního skla patři dále láhve určené $\mathrm{k}$ servírování vína, konkrétně láhve $\mathrm{s}$ uchem ze světle zeleného skla (tab. I:24, 25). Láhev s miskovitým ústím je ze skla typu mix-alkali a pravděpodobně pochází ze skláren v Hall (Sedláčková-Rohanová et al. 2016, 300, tab. 25, A387). Dvě láhve jsou z modrozeleného skla: menší čtyřboká hladká láhev ze skla sodno-popelového (tab. I:27), kdežto láhev se šikmými žebry a vysokým mírně kónickým hrdlem je ze skla draselno-vápenatého (tab. I:28, obr. 11; Sedláčková-Rohanová et al. 2016, 300, tab. 25, A388 a A389). V těchto lahvích byl patrně dovezen nebo uložen tvrdý alkohol.

Z hruškovitých zásobních lahví zůstaly spodní části se dny ovinutými vlákny a s nízkými patkami (tab. II:14-23) nebo kuželovitá hrdla s vykloněnými okraji (tab. II:7, 10-12). Zlomky horních částí, stěn a den jsou rovněž doloženy láhve čtyřboké různých velikostí ze světle zeleného nebo našedlého skla (tab. II:24, 26-27).

Nejspíše na výrobu alkoholu ukazuje velký zlomek destilačního přístroje - horní části cucurbitu - nádoby, ve které se zahřívala destilovaná tekutina (tab. II:31).

V souboru nechyběly ani lampy, a to dvou variant. Velkým překvapením jsou dvě olejové stolní lampy, z nichž jednu bylo možné rekonstruovat a $\mathrm{z}$ druhé zůstala jen část patky a dno (tab. II:1, 2; Ø těla 14,2 cm, Ø patky $7,5 \mathrm{~cm}$, v. ca $11,5 \mathrm{~cm}$ ). Lampy měly zploštěle kulovitá těla, posazená na dutých zvonovitých patkách. Tato varianta lamp ze sbírky na Veste Coburg je datována do konce 16. až 17. století (Theuerkauff-Liederwald 1994, 496, 497, č. kat. 620-623), lampa s erbem Alberta Saského nese letopočet 1677 (Saldern 1965, 202, obr. 358) a exempláře z Benátek jsou z doby kolem roku 1700 (Zecchin 2014, 47, obr. 4).

Z jiných bratislavských jímek a studní není tato varianta známá. V Bratislavě a Vídni byly rozšířené závěsné lampy s válcovitým až hruškovitým tělem, ve vodorovně vykloněném okraji většinou se zataveným bílým opakním vláknem, méně čirým modrým nebo červeným. Sklo bývá téměř bezbarvé se zeleným nebo modrým nádechem. Ve Vodné veži byly zlomky tř́ exemplářů s bílým a modrým vláknem, jedna bez vlákna v okraji (tab. II:3-5; Ø okr. ca $12 \mathrm{~cm}$ ). Další exempláře pocházejí z Bratislavského hradu (Maruniaková 1989, 330, obr. 18a). Ve studni na Ventúrské ulici jich bylo nejméně sedm, a to již ve vrstvách z první poloviny 16. století. Ve Vídni byly tyto lampy během 17. století i později používány na několika lokalitách v centru města (Tarcsay 2002, 179, tab. 4:1-6) a v Bratislavě také po roce 1700. Tvar vychází z benátských závěsných válcovitých lamp, v renesanci bohatě zdobených barevnými emaily (Dorigato 2006, 24, fig. 9), které se používaly i v královském paláci v Budě (Gyürky 1986, 32, tab. VII:1). Podobné lampy se v 17. století vyskytovaly rovněž v Nizozemí (Henkes 1994, 343, č. kat. 67.15 a 67.18). 


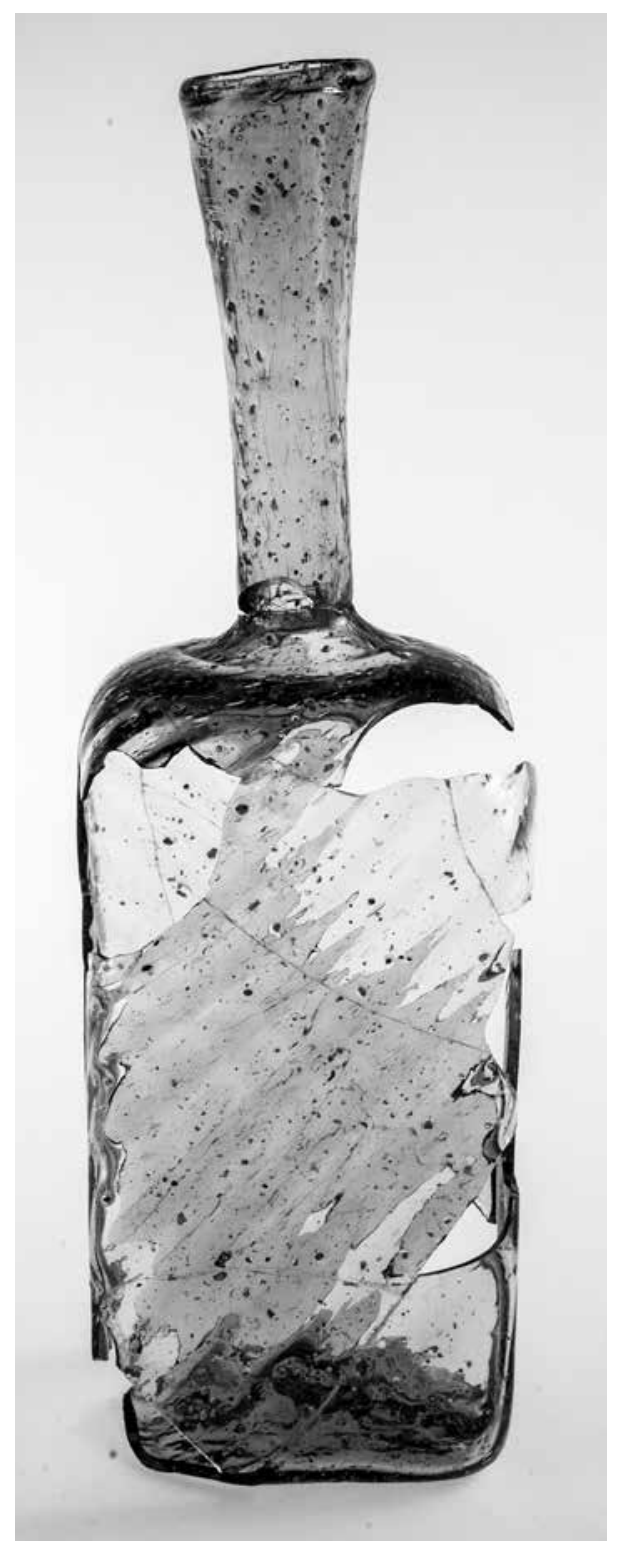

Obr. 11. Bratislava, Vodná veža, sonda 13, studna. Čtyřboká láhev s optickým dekorem žeber, regionální výrobek. Foto Miloš Strnad.

Abb. 11. Bratislava, Wasserturm, Sondierschnitt 13, Brunnen. Vierseitige Flasche mit optischem Rippendekor, regionales Erzeugnis. Foto Miloš Strnad.

kého materiálu je len minimálne. V súbore skla zo studne sú rovnako málopočetné. Tie, ktoré sa nám zachovali, možno zväčša považovat' za luxusné kusy. Sú datované hlavne do druhej polovice 16. storočia, kedy sa Bratislava stala významným exportérom vína. Je možné, že so
Analýzy několika bratislavských a vídeňských lamp ukazují vápenato-draselné sklo již téměř renesančního složení - pouze jedna, a právě z Vodné veže, byla z mix-alkali skla, snad vyrobená v Hall (Sedláčková-Rohanová et al. 2016, 300, tab. 25, A383). Místo výroby ostatních je nejasné, nejspíše v některé sklárně na území Rakouska nebo spíše Německa, odkud se ve druhé čtvrtině 16 . století dováželo sklo podobného složení.

Nálezy skla z Vodné veže poskytly zajímavé nové poznatky o společenském životě v Bratislavě ve druhé polovině 16. století. Existence pánských Stubengesselschaft ve městě dosud nebyla známa. Při bližším pohledu se ukazuje, že $\mathrm{v}$ souboru v podstatě chybí sklo luxusního charakteru, které známe ze všech bratislavských souborů, nebyl zde například žádný benátský pohár $\mathrm{s}$ bílým filigránem. Všechny poháry z Vodné veže pocházejí z regionálních skláren s produkcí skla draselného složení. Původ v Benátkách, resp. Itálii byl prokázán pouze u menší čtyřboké láhve a $\mathrm{i}$ v tomto prŕípadě byl nejspíše prredmětem dovozu obsah, nikoliv láhev jako taková. Benátský původ není vyloučen u konvičky či nádoby s nálepem s maskaronem. Relativně více výrobků bylo s velkou pravděpodobností vyrobeno v Hall - stolní láhev s uchem a závěsné lampy (prokázáno u jedné). Ostatně lampy dokládají vysoký standard či přímo luxus interiérů, více než nápojové sklo.

\section{Záver}

Vodná veža bola strategickým vojenským bodom pre mesto Bratislava i pre hrad a mýtnicou na medzinárodnej obchodnej ceste. Archívne pramene nám spomínajú, že svoj podiel na tunajšom mýte mali minimálne do polovice 14. storočia pannonhalmské a pilišské opátstvo, ako aj bratislavský župan. Neskôr svoje podiely prenajali alebo previedli na mesto Bratislava alebo na niektorých $\mathrm{z}$ bratislavských meštanov.

Odraz uvedených skutočností v archeologickom materiáli ale nenachádzame. Zastúpenie importov keramiky, skla či numizmatic-
zo studne sú rovnako málopočetné. Tie, ktoré 

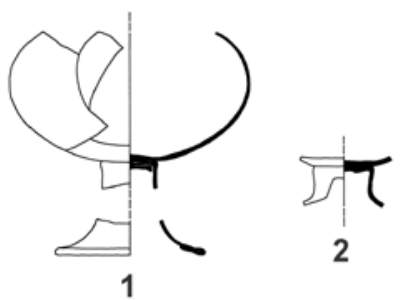

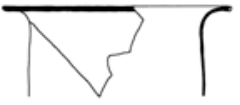

3

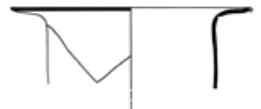

4

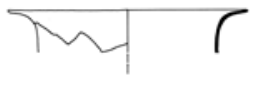

5

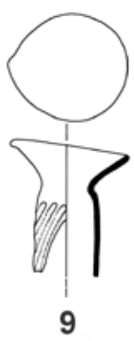

7

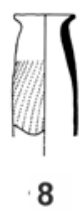

8

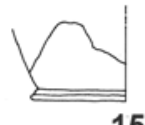

15

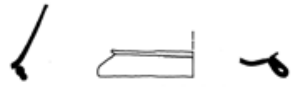

16

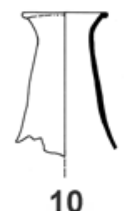

10

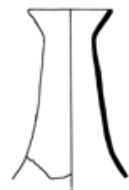

11

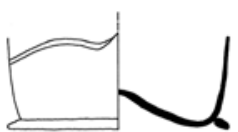

14

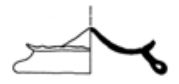

21

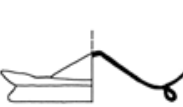

22

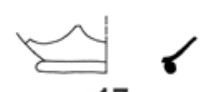

17

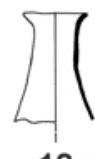

12

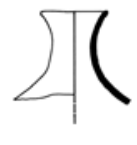

13

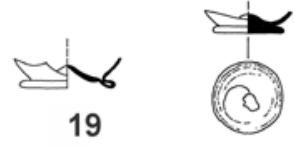

20

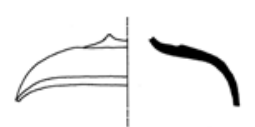

24

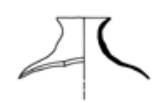

25

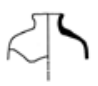

26

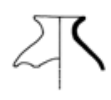

27

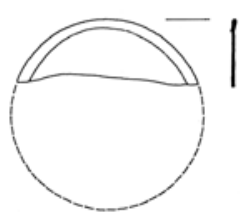

28

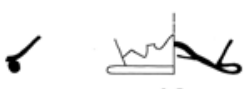

18

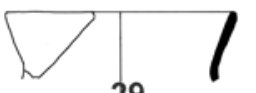

29

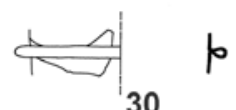

30

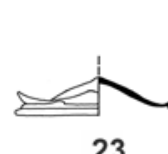

23

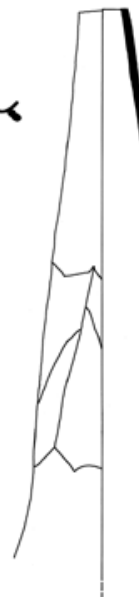

31

$0,5 \mathrm{~cm}$

Tab. II. Bratislava, Vodná veža. Sklo ze studny, sonda 13. Kresba Hedvika Sedláčková, technická úprava Lenka Sedláčková. Taf. II. Bratislava, Wasserturm. Glas aus dem Brunnen, Sondierschnitt 13. Zeichnung Hedvika Sedláčková, technische Aufbereitung Lenka Sedláčková. 
zvyšujúcou sa kvalitou vína, s rastúcim exportom sa zvyšovala aj kultúra pitia a tunajší spotrebitelia si potrpeli aj na podávaní vína.

Vojenská funkcia Vodnej veže sa $\mathrm{v}$ archeologickom materiáli odrazila len minimálne. Otázne je, či výsledok ovplyvnila absencia časti prírastkového zoznamu, alebo väčšie zbrane a výstroj boli pri ohrození strategického bodu prest’ahované do mesta, a tak sa nám ani nemohli zachovat'. Napriek uvedeným zisteniam by podrobné publikovanie rozsiahleho súboru archeologických nálezov z Vodnej veže v Bratislave bolo prínosné, no nebolo to cielom predloženej štúdie.

\section{Pramene a literatúra}

ARCHÍV MÚOP v Bratislave, inv. č. 4498 B, Vodná veža.

ARCHÍV MÚOP v Bratislave, inv. č. 4498 I, Vodná veža.

BAĎURÍK, J., 1987: Obchod s malokarpatským vínom v období neskorého feudalizmu. In: K dejinám obchodu na Slovensku. Zborník prednášok z konferencie, 50-54. Bratislava.

- 1990: Malokarpatské vinohradníctvo v 16. storočí. Bratislava.

- 2005: Z dejín malokarpatského vinohradníctva a vinárstva. In: Malík, F. a kol., Víno Malých Karpát. Krajina - l'udia - tradícia, 32-57. Bratislava.

- 2005a: Vinohradnícke lokality Malých Karpát. In: Malík, F. a kol., Víno Malých Karpát. Krajina - l’udia tradícia, 61-129. Bratislava.

BARTL, J., 1963: Mýta na Malom Dunaji vo vzt’ahu k Bratislave a bratislavskému mýtu. Príspevok k topografii bratislavských mýt, ZbSNM LVII - História 3, 51-66.

- 1970: Bratislavský obchod v stredoveku, Zborník FF UKO - Historica XXI, 87-112.

- 1982: Stredoveký hrad, podhradie a mesto do roku 1291. In: Dejiny Bratislavy (Horváth, V.-Lehotská, D.Pleva, J., edd.), 44-50. Bratislava.

- 1982a: Obchod a remeslá v 14. storočí. In: Dejiny Bratislavy (Horváth, V.-Lehotská, D.-Pleva, J., edd.), 68-71. Bratislava.

BARTL, J.-HUDÁKOVÁ, H., 1982: Sociálna a národnostná štruktúra bratislavského obyvatelstva v 14. a 15. storočí. In: Dejiny Bratislavy (Horváth, V.-Lehotská, D.-Pleva, J., edd.), 60-63. Bratislava.

BAXA, P.-FERUS, V., 1991: Bratislava mešt'ana Wocha (1243-1291). Bratislava.

BAXA, P.-FERUS, V.-KLINČOKOVÁ, K., 1989: Neznáma veža Vodnej veže v Bratislave? - Ein unbekanter Turmbau des Wasserturms in Bratislava?, AH 14, 161-169.

DORIGATO, A., 2006: The Glass Museum. Venice.

- 2013: Murano Island of Glass. Venice.

DURDÍK, J., 1967: Bratislavský inventár palných zbraní z r. 1443, Historie a vojenství 4, 573-592.

EGG, E., 1962: Die Glashütten zu Hall und Innsbruck im 16. Jahrhundert. Tiroler Wirtschaftsstudien Schriftenreihe der Jubiläumsstiftung der Kammer der gewerblichen Wirtschaft für Tirol 15. Innsbruck.

FEDERMAYER, F., 2003: Rody starého Prešporka. Genealogický rozbor obyvatel'stva a topografia mesta podla súpisu z roku 1624. Bratislava / Pressburg / Poszony.

FIALA, A., 1974: Správa o nálezoch jednotlivých mincí, resp. medailí pri archeologickom výskume „Vodnej veže“, resp. Podhradia v Bratislave, rkp. ulož. v Archíve MÚOP v Bratislave, inv. č. 4498 A.

- 1982: Svetská architektúra. In: Dejiny Bratislavy (Horváth, V.-Lehotská, D.-Pleva, J., edd.), 79-85. Bratislava.

FIALA, A.-PLACHÁ, V.-VALLAŠEK, A., 1967: Bratislavská Vodná veža (Doterajšie výsledky výskumu). In: Bratislava. Spisy Mestského múzea v Bratislave. Zv. III, 41-58. Bratislava.

FORBAT, E., 1959: Dejiny bratislavského obchodu v 18. a 19. storočí (1699-1873). Bratislava.

GYÜRKY, K. H., 1986: Az Üveg katalógus. Budapest.

HALAGA, O., 1987: Podiel Slovenska na európskom obchode v stredoveku. In: K dejinám obchodu na Slovensku. Zborník prednášok z konferencie, 31-40. Bratislava.

HEJL, F., 1987: Místo a význam východoslovenských měst a jejich hospodářská funkce v středoevropských směnných vazbách za pozdního feudalismu. In: K dejinám obchodu na Slovensku. Zborník prednášok $\mathrm{z}$ konferencie, 41-49. Bratislava.

HENKES, H. E., 1994: Glaszonderglans - Glasswithoutgloss. A contribution to medieval and post-medieval archaeology. Rotterdam Papers 9. Rotterdam.

HORNA, R., 1935: O Bratislavském vinařství. Bratislava. 
HUDÁKOVÁ, H., 1982: Hospodársky rozmach slobodného král’ovského mesta. In: Dejiny Bratislavy (Horváth, V.-Lehotská, D.-Pleva, J., edd.), 63-68. Bratislava.

JANKOVIČ, V., 1982: Formovanie mesta. In: Dejiny Bratislavy (Horváth, V.-Lehotská, D.-Pleva, J., edd.), 41-43. Bratislava.

JANKOVIČ, S.-BAUEROVÁ, G.-MACHOVÁ, A., 1984: Gotické architektonické pamiatky Bratislavy. Bratislava.

JANOVÍČKOVÁ, M., 2001: Benátske sklárstvo - inšpirácia pre Európu, Pamiatky a múzeá 4, 46-47.

JORDÁNKOVÁ, H.-SEDLÁČKOVÁ, H., 2005: Skleněné stř́ípky z domácnosti Matouše Židlochovického Glasscherben aus dem Haushalt von Matouš Židlochovický, BMD 18, 119-143.

JURÁNYI, L., 2013: Najstaršia pozemková kniha - Grundbuch (1439-1517). In: Bratislava XXV. Zborník Múzea mesta Bratislavy, 21-53. Bratislava.

- 2014: Prešporské vinice koncom stredoveku v zrkadle najstaršej pozemkovej knihy mesta. In: Bratislava XXVI. Zborník Múzea mesta Bratislavy, 7-36. Bratislava.

KALESNÝ, F., 1982: Vinohradníctvo a vinárstvo. In: Dejiny Bratislavy (Horváth, V.-Lehotská, D.-Pleva, J., edd.), 71-73. Bratislava.

KAZIMÍR, Š., 1986: Pestovanie viniča a produkcia vína na Slovensku v minulosti. Bratislava.

- 1987: Problémy dejín obchodu neskorého feudalizmu. In: K dejinám obchodu na Slovensku. Zborník prednášok z konferencie, 19-30. Bratislava.

KLINČOKOVÁ, K.-FERUS, V., 1982: Stavebno-historický vývoj Vodnej veže v Bratislave. In: Pamiatky a príroda Bratislavy 7, 109-132. Bratislava.

KLINČOKOVÁ, K.-FERUS, V.-KAMENICKÁ, V., 1986: Výskumná správa (čiastková správa zo stavebno-historického výskumu lokality Bratislava - Vodná veža, 1986), rkp. ulož. v Archíve MÚOP v Bratislave, inv. č. $4498 \mathrm{~B}$.

KOVAČOVIČOVÁ-PUŠKÁROVÁ, B. a kol., 1968: Kovačovičová-Puškárová, B.-Jankovič, V.-Nosálová, I.-Ladovanová, H., Bratislava - Vodná veža (pamiatkový zámer), rkp. ulož. v Archíve MÚOP v Bratislave, inv. č. 4498 A.

KRAUS, F., 1939: O bratislavském vinařství. Bratislava.

LAMÉRIS, K., 2013: Vetro a retortoli: thoughts about dating. Part 1, Glass Circle News 36, no. 3, 16-21.

LESÁK, B., 2009: Súbor renesančného skla z Ventúrskej ulice 3 v Bratislave - Collection of Renaissance Glass from 3 Ventúrska Street in Bratislava, ŠZ AÚ SAV 46, 23-29.

LYSÁ, Ž., 2010: Bratislava. In: Štefánik, M.-Lukačka, J. a kol., Lexikon stredovekých miest na Slovensku, 105-139. Bratislava.

- 2014: Bratislava na ceste k privilégiu 1291. Štúdie k dejinám Bratislavy v 13. storočí. Bratislava.

MARUNIAKOVÁ, M., 1989: Súbor skla u Bratislavského hradu - Die Glaskollektion aus der Burg von Bratislava, Zborník FF UKO Historica XXXIX-XL, 295-335.

- 1991: Záchranné výskumy archeologického oddelenia MSPS OP v historickom jadre Bratislavy. In: AVANS 1989, 65. Nitra.

PIFFL, A., 1972: Bratislava - Vodná veža (nálezová správa), rkp. ulož. v Archíve MÚOP v Bratislave, inv. č. $4498 \mathrm{~A}$.

SALDERN, v. A., 1965: German Enameled Glass. Corning, N. Y.

SEDLÁČEK, P., 2012: Vojenstvo v Bratislave v polovici 15. storočia vo svetle komorských kníh. Diplomová práca, Katedra archívnictva a pomocných vied historických, Filozofická fakulta Univerzity Komenského, Bratislava.

- 2013: Konrád Shiler, strážca a trubač v stredovekej Bratislave. In: Bratislava XXV. Zborník Múzea mesta Bratislavy, 9-20. Bratislava.

SEDLÁČKOVÁ, H.-ROHANOVÁ, D. et al., 2016: Renaissance and Baroque Glass from the Central Danube Region. Brno.

SEGEŠ, V., 1998: Historické črty zástoja miest na Slovensku v uhorskom stredovekom vojenstve, Vojenská história 2, č. 1, 3-20.

SCHEICH, D., 2015: Ein Stangenglas des 16. Jahrhunderts aus dem Sünfzen zu Lindau, Der Glasfreund Zeitschrift für altes und neues Glas 20, Nr. 56, 17-21.

ŠÁS̆KY, L., 1997: Pamiatky Bratislavy. Učebné texty pre vlastivedných sprievodcov po Bratislave. Bratislava.

TARCSAY, K., 2002: Neue Erkentnisse zum Spektrum des mittelalterlichen und neuzeitlichen Glases in Wien. In: Fundort Wien. Berichte zur Archäologie 5, 168-191. Forschungsgesselschaft Wiener Stadtarchäologie. Wien. 
THEUERKAUFF-LIEDERWALD, A.-E., 1994: Venezianisches Glas der Veste Coburg. Die Sammlung Herzog Alfreds von Sachsen-Coburg und Gotha (1844-1900). Lingen.

VREEKEN, H., 1998: Glas in het Amsterdams Historisch Museum en Museum Willet-Holthuysen. Amsterdam.

ZECCHIN, P., 2014: The inventory of Matteo Priuli in the year 1700. In: Atti Classe di Scienze Fisiche, Matematiche e naturali 172-1. Istituto Veneto di Scienze, Lettere ed Arti, 43-47. Venezia.

ZMLUVA č. 2/2003 o odovzdaní - prevzatí nálezov mincí z archeologického výskumu Vodná veža, ŠMPR Bratislava, záchranný archeologický výskum, Mgr. K. Klinčoková, rkp. ulož. v Archíve MÚOP v Bratislave.

\section{Zusammenfassung}

\section{Leben an der Stadtgrenze. Ein Beitrag zu den Ergebnissen der archäologischen Grabung am Wasserturm in Bratislava}

Für die Stadt Bratislava und für die Burg war der Wasserturm ein militärisch-strategischer Punkt und diente gleichzeitig als Zollstation an einem internationalen Handelsweg. Die Archivquellen besagen, dass mindestens bis Mitte des vierzehnten Jahrhunderts drei Subjekte an den dortigen Zolleinnahen ihre Anteilsbeteiligung hatten, die Abteien Pannonhalma und Pilis, sowie das Komitat Pressburg. Später haben sie ihre Anteile verpachtet oder auf die Stadt Bratislava bzw. auf einige Bürger der Stadt Bratislava übertragen.

Die genannten Fakten werden im archäologischen Material jedoch nicht widergespiegelt. Das Vorkommen von importierter Keramik, importiertem Glas und numismatischen Material ist nur minimal. In dem Fundkomplex des aus dem Brunnen in Sondiergrabung 13 stammenden Glases sind Importgegenstände ebenfalls nur in geringer Anzahl vorhanden. Die erhalten gebliebenen Stücke kann man als Luxusgegenstände betrachten. Sie werden hauptsächlich in die zweite Hälfte des 16. Jahrhunderts datiert, als Bratislava zu einem bedeutenden Exporteur von Wein wurde. Es ist möglich, dass sich mit der steigenden Weinqualität und dem Exportanstieg auch die Trinkkultur verbesserte und die dortigen Verbraucher bereits eine Vorliebe für das Kredenzen von Wein hatten. Die Funde des analysierten Komplexes belegen die Existenz einer bis dahin in dieser Stadt unbekannten sog. Stubengesellschaft. In dem Fundkomplex fehlen jedoch Luxusglastypen, die in den aus Bratislava stammenden Fundkomplexen vorkamen. Beispielsweise wurde dort kein venezianischer Becher mit weißem Filigran entdeckt. Alle Becher aus dem Wasserturm stammen aus regionalen Glashütten mit Pottascheglasproduktion. Eine Herkunft aus Venedig bzw. von der Apeninnenhalbinsel wurde lediglich bei einer kleineren vierseitigen Flasche nachgewiesen. Aber auch in diesem Fall könnte eher der Inhalt als die Flasche selbst der Grund für den Import gewesen sein. Eine venezianische Herkunft lässt sich bei einer Aufschmelzung mit Maskaron nicht ausschließen. Mehrere Funde des Komplexes stammen wahrscheinlich aus der Glashütte in Hall, eine Tafelflasche mit Henkel und Hängelampen. Die Lampen selbst belegen im Übrigen den hohen Standard der Ausstattung von Innenräumen.

Die militärische Funktion des Wasserturms wurde im archäologischen Material nur minimal widergespiegelt. Es ist fraglich, ob unser Ergebnis davon beeinflusst wurde, dass ein Teil des Zuwachsverzeichnisses fehlt, oder ob die meisten Waffen und Ausrüstungsgegenstände während einer Bedrohung des strategischen Punktes in die Stadt gebracht wurden und sich dort somit nicht erhalten haben können. Trotz der genannten Feststellungen wäre eine detaillierte Veröffentlichung des umfangreichen Komplexes der im Wasserturm von Bratislava gemachten archäologischen Funde lohnenswert, was jedoch kein erklärtes Ziel der hier vorgelegten Studie war.

Mgr. Petra Šimončičová Koóšová, PhD., Mestský ústav ochrany pamiatok v Bratislave, Uršulínska 9, SK 81101 Bratislava, Slovenská republika,almos@post.cz 
PhDr. Hedvika Sedláčková, CSc., Archaia Brno o.p.s., Bezručova 15/78, 60200 Brno, Česká republika, hedvika.glass@seznam.cz

PhDr. Branislav Lesák, Mestský ústav ochrany pamiatok v Bratislave, Uršulínska 9, SK 81101 Bratislava, Slovenská republika, branislav.lesak@gmail.com

Dr. Ing. Dana Rohanová, Ústav skla a keramiky, Vysoká škola chemicko-technologická v Praze, Technická 5, 16628 Praha 6, Česká republika, dana.rohanova@vscht.cz 
